\title{
Family Migration and the Path to an Occupation
}

This book sheds light on the invisible early post-arrival period of female family migrants, traditionally considered to be low skilled or professionally quiescent. With attention to the experiences of Chinese and Taiwanese women married to German men, it examines the ways in which the private sphere-marked by intermarriage couple dynamics and native-foreigner relations-constitutes the main locus of women's socialization in the host country, as interactions with their intimate partners in the family realm shape both their self-conceptions and their employment intentions. Based on interviews with migrant women and their spouses, the author outlines the subject positions that characterize female migrants' attitudes to external constructs and entering the labor market, showing that female family migrants frequently take on family migrant and wife roles that permeate intimate relationships and impede employment intentions, but also often strive to realign with their pre-departure independent selves and thus regain agency. A study of gender dynamics and labor market entry among newly arrived female migrants, this volume will appeal to scholars of sociology with interests in gender, migration, and work.

Chieh Hsu is Researcher at the Global Asia Research Center at National Taiwan University, Taiwan. 


\section{Research in Migration and Ethnic Relations Series}

Series Editor: Maykel Verkuyten, ERCOMER Utrecht University

The Research in Migration and Ethnic Relations series has been at the forefront of research in the field for ten years. The series has built an international reputation for cutting edge theoretical work, for comparative research especially on Europe and for nationally-based studies with broader relevance to international issues. Published in association with the European Research Centre on Migration and Ethnic Relations (ERCOMER), Utrecht University, it draws contributions from the best international scholars in the field, offering an interdisciplinary perspective on some of the key issues of the contemporary world.

The Construction of European Identity among Ethnic Minorities

Euro-Minorities in Generational Perspective

Natalia Waechter

Intra-State Immigrants as Sub-State Nationalists

Lived Experiences in the Basque Country

Nick Hutcheon

Family Migration and the Path to an Occupation

The (Early) Experiences of Skilled Taiwanese and Chinese "Wives" Chieh Hsu

For more information about this series, please visit: https:/www.routledge. com/sociology/series/ASHSER1136 


\section{Family Migration and the Path to an Occupation}

The (Early) Experiences of Skilled

Taiwanese and Chinese "Wives"

\section{Chieh Hsu}

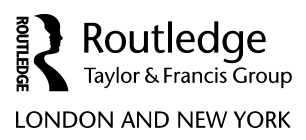


First published 2020

by Routledge

2 Park Square, Milton Park, Abingdon, Oxon OX14 4RN

and by Routledge

52 Vanderbilt Avenue, New York, NY 10017

Routledge is an imprint of the Taylor \& Francis Group, an informa business

(C) 2020 Chieh Hsu

The right of Chieh Hsu to be identified as author of this work has been asserted by her in accordance with sections 77 and 78 of the Copyright, Designs and Patents Act 1988.

All rights reserved. No part of this book may be reprinted or reproduced or utilised in any form or by any electronic, mechanical, or other means, now known or hereafter invented, including photocopying and recording, or in any information storage or retrieval system, without permission in writing from the publishers.

Trademark notice: Product or corporate names may be trademarks or registered trademarks, and are used only for identification and explanation without intent to infringe.

British Library Cataloguing-in-Publication Data

A catalogue record for this book is available from the British Library

Library of Congress Cataloging-in-Publication Data

Names: Hsu, Chieh, 1985- author.

Title: Family migration and the path to an occupation : the (early)

experiences of skilled Taiwanese and Chinese 'wives' / Chieh Hsu.

Description: Milton Park, Abingdon, Oxon ; New York,

NY : Routledge, 2020. | Includes bibliographical references and index.

Identifiers: LCCN 2020008344 (print) | LCCN 2020008345 (ebook) |

ISBN 9780367424312 (hardback) | ISBN 9780367824075 (ebook)

Subjects: LCSH: Women immigrants--Social conditions. | Women

immigrants--Germany--Social conditions. | Chinese--Foreign

countries--Social conditions. | Taiwanese--Foreign countries--Social

conditions. | Chinese--Germany--Social conditions. |

Taiwanese--Germany--Social conditions.

Classification: LCC HQ1760.5 .H78 2020 (print) | LCC HQ1760.5 (ebook) |

DDC 305.48/412--dc23

LC record available at https://lccn.loc.gov/2020008344

LC ebook record available at https://lecn.loc.gov/2020008345

ISBN: 978-0-367-42431-2 (hbk)

ISBN: 978-0-367-82407-5 (ebk)

Typeset in Times New Roman

by Taylor \& Francis Books 


\section{Contents}

List of illustrations $\quad$ vi

Acknowledgements vii

Preface viii

\section{PART 1}

Placing women in the migration context 1

1 Professionals? Migrants? Wives? Who are these women? 3

2 Women on and after the move 29

3 Home-country contexts vs. host-country realities 51

\section{PART 2}

Understanding skilled "wives" experiences

4 An evolving self tied to roles: Re-envisioning the immersion period

5 An insider's approach

\section{PART 3}

Navigating the new and bridging the gap

6 Marriage and dependency back home and in Germany

7 Embracing dependency: Passive autonomy

8 Reclaiming independence: Active autonomy

9 Conclusion 


\section{Illustrations}

\section{Figures}

1.1 Timeline of Recruitment in Three Phases 16

1.2 First Wave Distribution Map 21

1.3 Second Wave Distribution Map 22

\section{Tables}

1.1 Final Ten Sites and Main Course Provider in the Area 13

1.2 List of Online Recruitment Bulletins and Groups 15

1.3 Confirmed Research Participants by Recruitment Method 16

$\begin{array}{ll}1.4 \text { Sample Overview } & 17\end{array}$ 


\section{Acknowledgements}

This book, as an extension of my doctoral thesis, overlapped with a time where uncertainties abound and a stop to improbable circumstances in the offing seems out of reach. I am therefore exceptionally grateful to all those who had provided support, be it practical or moral. I would like to thank Professor Dr. Kathia Serrano-Velarde, who believed in a novice in sociology and offered me a beacon of hope on the path of doctoral research. I appreciate her diligence, dedication, and constructive academic guidance that also allowed much room for exploration. I am indebted to her efforts in securing additional resources for me to facilitate my research on campus and as an independent doctoral student. Professor Dr. Julia Nentwich generously took me under her wing and led me to a wealth of methodological resources in social psychology that have greatly benefited my research. The original dissertation wouldn't have seen the light of day without her scholarly input and warm mentorship.

I thank all the interviewees who agreed to participate in my study and share their stories with me, often of joy, but also of sweat and tears. I am deeply moved and humbled that they each entrusted me with a portion of their lives that collectively made this book possible. I also thank the Heidelberg Graduate School for the Humanities and Social Sciences and Geschwister-Supp-Foundation for financing my research and having good faith in my project.

I dedicate this book first and foremost to my parents, Kan-Tsao and Wen-Fa, who gave me life and love and made me who I am today. To my family and friends who believe in me, and to Ann, who walked me through all those tortuous days and doused me with clarity, optimism, and strength. Most importantly, this is for Eliora, who was there, loving and hugging me at every turn, grew with me and helped me grow, and offered me a chance to know myself once again. I hope she reads this piece of work one day, knowing that she contributed immensely to my enhanced reflexivity and sensitivity, without which this final product wouldn't have its present mellowness. I would also unconventionally thank myself, for pulling through unthinkable crises, staying strong, and persevering. Lastly, this work, though feeble, is to salute all women who not only held up at least half the sky, but cemented pretty much all the ground there is in Taiwan. 


\section{Preface}

There has been surging interest in studying female migration-women who move as dependents, spouses, or independent economic migrants or professionals. Scholars have examined how female migrants navigate the migratory process vis-à-vis host-country institutional constraints and sought to understand their place and lives at the destination. There is also no shortage of research dedicated to benchmarking how female migrants perform in the host society in comparison to native women. What is, however, less visible and visited is the specific cohort of migrant women who move to marry or join their foreign spouses while simultaneously carrying skills resembling those of highly qualified professionals. This book responds to such a lacuna by exploring the early postarrival period of an ethnically homogeneously group of Taiwanese and Chinese skilled women married to German husbands in Germany. I particularly set out to unveil how the dynamics of their intercultural marriage and dyadic interactions affect these women's acculturation, evolving self-conceptions, and intentions to (re)join the German labor market.

What underlies and distinguishes the inquiry of this book is my motivation to understand how other women in similar situations cope. As a Taiwanese family migrant myself, I was acquainted with the administrative hurdles and rigid regulations that most third-country dependent migrants in Germany had encountered. Nevertheless, it was the challenges in the private sphere that caught me off guard and agitated me to a far greater extent. Little did I foresee how the contour of my life after arrival in Germany would be so thoroughly dictated and shaped by my intimate relationship. Moreover, the domination of the domestic spilled over to influence how I perceive German society, my approach to engaging with its people and institutions, and my personal decision-making. It wouldn't be an understatement to say that my outlook on partnership and family life, as well as my long-term orientation, have dramatically shifted as a result. Hence, I wondered whether these were shared experiences among other foreign wives (foreign as in the eyes of the native or majority population) who engaged in gainful employment before moving as dependents. More specifically, I am intrigued by how educated, skilled, even professionally accomplished women grapple with the evident gap between labor force participation and employment hiatus. 
The most apt way to capture the subtle yet momentous changes in subjective perceptions, I decided, was to "accompany" these skilled female family migrants' preliminary stage after arrival. Instead of looking at women who have been in Germany for a longer period of time and are somewhat more "seasoned" in their migrant status and "grounded" in the host society, I was particularly interested in identifying new arrivals" incremental changes. These changes may be reflected in dimensions such as emotionality, mentality, selfawareness, and life aspirations; more importantly, they are also instrumental in determining how these women establish relations with the receiving society and in steering the course of their future integration.

I divided this book into three parts in the hope of providing sufficient background of the field of interest and contextualizing my research before diving into these women's stories. They revealed that female family migrants' early postarrival experiences in Germany are to be viewed alongside their pre-departure circumstances and home-country factors and are intricately embedded in the intercultural household. These women's path to an occupation and trajectory of pursuit are for that matter dependent on preexisting work commitment (relevant to their self-conceptions and identity) and prescribed by external constraints and gendered realities in Germany.

I unpack in Chapter 1 the term female family migrant and underline the multiple and often neglected statuses and categories that migrant women occupy concurrently. Departing from the recognition that the nature of migration can be complex, I elaborate on the objective and the necessity of studying skilled female family migrants and their early arrival - "immersion period"-in this new light. Chapter 2 scans existing research on female family migration that encompasses the entire spectrum of the migratory timeline. Stretching from the point of admission and further demarcated by the mode of entry, studies tend to focus on migrants' later stages in the host country, where their level of integration and achievements are evaluated against those of natives. I emphasize additionally the ever more intertwined and intersecting labels, if not "identities," that characterize modern-day migrant women, a key theme in female migration literature.

Resting on the broader landscape of female migration literature, Chapter 3 zooms into the sending and receiving societies that mark the pre-departure and post-arrival realities of these Taiwanese and Chinese women in Germany. I focus on dissecting the multifarious contextual and structural factors that shape who they have been at home and constrain their professional, occupational developments once they arrive in the host country. I underscore that the social atmosphere, policy arrangements, and labor market conditions in Germany are utterly different from those of these women's home countries. By rendering precision to them, I argue that these elements further entrench their "situatedness" in the family sphere.

Chapter 4 introduces a reconceptualization of skilled wives' early postarrival experiences rooted essentially in the symbolic interactionist framework and enhanced by interactional role theory. It emphasizes how the immersion 


\section{Preface}

period beginning immediately after arrival is constructed upon role-related (the wife and family migrant roles), expectation- and value-laden social interactions with natives that affect these migrant women's self-conceptions. I argue that these gendered, role-oriented impositions inevitably trigger selfrecalibration or readjustment. I shift gear in Chapter 5 to discuss my unique positionality and "situatedness" throughout the research. Sharing the family migrant status with my interviewees is a privilege that allowed for access into and trust within the community, although not without its limitations. I deliberate on the impact that my role as an insider and a researcher has on the project and the implications of such a methodological approach.

Chapter 6, marking the transition to skilled female family migrants' stories, discloses the hidden yet substantial difference between home- and host-country contextual factors, which harbor divergent notions of female dependency. Bridging this attitudinal gap and negotiating dependency in their intercultural marriage in Germany hence constitute the "main hurdle" for some Chinese-speaking skilled wives. Their intentions to reenter the labor market are in turn a reflection of how they approach the institutionally normalized and widely practiced female dependency in Germany.

The constellation between skilled wives' preestablished self-conceptions and their newfound state of dependency through marriage legitimated in the German society lays the foundation for Chapters 7 and 8. Interview narratives in Chapter 7 showcase that a few skilled women did not conceive financial independence and autonomy before migration as a crucial part of their identity and readily embraced dependency facilitated by migration and marriage. On the contrary, interviews in Chapter 8 speak volumes about how most skilled female family migrants deem employment a vital source of self-worth and autonomy, which define their "selves" and identity. These women strove to rejoin the job market or alternatively engage in meaningful occupations to practice and regain their autonomy.

I conclude in Chapter 9 that the path to occupation is a strenuous one among the newly arrived skilled Taiwanese and Chinese wives to whom I spoke. Not least because of the structural constraints inherent in the German labor market, but their dependent status as wives and family migrants confines them to the private sphere of the household, which is governed by intimate power dynamics and gendered division of labor. Finding a way to "occupy" themselves through gainful employment is thus a means to break away from dependency and partially defy the rigid gender norms in the family, a process through which they find their "selves." 
Part 1

Placing women in the migration context 


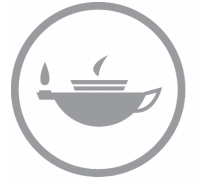
Taylor \& Francis Taylor \& Francis Group http://taylorandfrancis.com 


\section{Professionals? Migrants? Wives? Who are these women?}

International migration used to be equated with men's cross-border movements. The imagery of a single male economic migrant was so pervasive - as was befitting the time before the 1970s and mirroring the prevalence of postwar guest-worker programs - that it dominated scholarly inquiries in the field (Kofman 1999:269). This absence of a female perspective on global mobility was only redressed during the last quarter of the 20th century when researchers began to recognize, theorize, and nuance the trend of the "feminization of international migration" (Castles and Miller 2009, King 2002, Kofman 1999, Kofman et al. 2000, Morokvasic 1984). Previously altogether invisible (Kofman 2000), female migrants first received academic attention as wives trailing or joining their husbands through the pathway of family reunification. Though later recast as independent actors who exercise international mobility (King 2002), migrant women inspiring early studies were still predominantly the unskilled or lowly skilled workers. Only of late, riding the wave of research emphasis on the global movements of highly skilled and professional migrants during the $1980 \mathrm{~s}$, did qualified skilled female migration begin to garner ascending interests (King 2002, Koser and Salt 1997, Salt 1992). As a result, initiatives in investigating the trajectories of skilled female professional migrants prospered as the trends of studying female and skilled migration converge. Women thus became the subjects of a burgeoning subfield that explores the experiences of skilled female economic migrants (Castles and Miller 2009, Catarino and Morokvasic 2013, Docquier, Lowell and Marfouk 2009, Docquier et al. 2012, Ho 2006, Iredale 2005, Kofman 1999, Kofman 2000, Kofman et al. 2000, Koser and Salt 1997, Morokvasic 1984, Salt 1992, Zlotnik 1990, 1995).

While projects examining skilled female labor migration continue to yield fecund insights into why women move, their work-related performance in the host society, and their level of long-term integration, only a paucity of research is dedicated to female family migrants who are highly skilled. Professional migrant workers and dependent family migrants seem to be conceptually distinct and discrete categories that women concurrently exhibiting qualities or traits of both have consistently, if not thoroughly, been overlooked as potential research subjects. Another issue no less perturbing in studying 


\section{Placing women in the migration context}

migrant women, however, is the distorted lenses that have inhabited and monopolized our imagination and through which we have come to simplify and homogenize these women's migratory experiences.

It is precisely against the above backdrop that this research contributes to a more layered and dynamic analysis of highly skilled female family migrants' early adaptation. I first and foremost recognize that these women acquire their "family migrant" status much later than their pre-migration specialized training and professional life. Their post-arrival experiences thus cannot be viewed without factoring in the dimension of pre-departure occupational engagement. In addition, the intimate relations with their significant others and the private sphere of the family are bound to exert influence over not only their day-to-day accommodation in the host society, but also their employment-related considerations and decisions. I also stress in this research how we should not underestimate the challenge migration triggers, even when looking at "voluntary" as opposed to "forced" migration. I strive to nuance the multitude of facets that call for these women's adjustment due to their "gendered" role in the family and as migrants. On the other hand, I seek to "rectify" the false "voiceless, subservient" stereotype attached to these women and emphasize the various ways they exercise agency once hurled into the destination country.

Below I provide a sketch of the two overlooked subjects that have less often been conjointly and thematically treated in the study of female family migration. An overview of the research on which this book is based, including its scope, design and methodology, and the data collected, follows.

\section{The hidden intersection of female skilled and family migration}

The conceptual shift that prompted scholars to consider the unique juncture of female family migrants and their skills can be attributed to the European Union-wide migratory regime change in the 1970s. The guestworker regime practiced by countries such as Germany, France, Switzerland, the United Kingdom, and the Netherlands in the post-war eras (Kofman et al. 2000, Kofman et al. 2011, Raghuram 2004) was followed by family migration in its most quintessential form, "depicted as consisting primarily of family reunification with the pioneering male being followed by the dependent female who only marginally, if at all, participated in the labor market" (Kofman et al. 2011:14). Yet, upon the termination of guest-worker programs and the enforcement of further restrictions on labor migration, family formation or marriage migration became "almost the sole means of entry to, and continuing residence in, the EU for thirdcountry nationals, especially those who do not have the recognised skills" (Kofman et al. 2011:18). A seismic regime transition as such sparked renewed economic interests in understanding how existing stocks of family migrants in destination countries, consisting mostly of women, can best utilize their skills and be integrated into the labor force. 
This fast-growing recognition of women as professional migrants (Mollard and Gagnon 2014) coincided with numerous studies that target female family migrants as research subjects. Most of those on the latter are nonetheless engrossed with the visible cultural, ideological, and economic hurdles of their becoming properly integrated marriage migrants (Bonjour and de Hart 2013, Bonjour and Kraler 2015). The inquiry into their employment prospects in the host country consequently stays overshadowed by their principal status as a family migrant and is grounded in the prominent impression of their inadequate training and credentials, which augments the presumption of their below-average labor market participation (Bonjour and Kraler 2015, Kofman, Saharso and Vacchelli 2013). As a result, there has been a dearth of studies that regard female family migrants as skill bearers, let alone those setting out to unravel their postmigration employment trajectories in the country of immigration. Among the available work primarily located in the field of labor migration that attend to or underscore female migrants' skills, types and patterns of their employment, along with the level of their skill transfer and utilization, appear to be common themes of these studies. The conclusions drawn unequivocally suggest that women practicing family or tied migration are particularly vulnerable to lowered employment status (Bailey and Cooke 1998, Boyle et al. 2001). It is nevertheless to be noted that literature thoroughly devoted to the experiences of highly skilled female migrants is sporadic at best (Meares 2010). Research dedicated to the direct linkage between marriage migrants and their subsequent employment situations in host countries is even more sparse (Jakobsen and Liversage 2017). The unveiling of skilled female migrants' migratory trajectories, especially those primarily distinguished by their family or marriage dependent status, has therefore been piecemeal and accrued relatively fragmented knowledge. There are "relatively" few studies at hand (Aure 2013, Liversage 2009a, 2009b, Man 2004, Purkayastha 2005, Raghuram 2004, Riaño 2011, 2014, 2015, Yeoh and Willis 2005) that cater to skilled women who enter host countries through tied migration, for love, or as spouses, hence the category's exclusion and low visibility within the study of female migration.

\section{Distorted and reductionist lenses}

If the skill aspect of female family migration has largely been overlooked, the unimodal lens through which female spouses are scrutinized and the consequent monotony in presenting them as actors in international migration are disproportionately overpowering. In Europe, where family reunification remains the dominant channel through which migrants arrive, women, constituting the majority of family migrants, occupy the center stage of most analyses on this migrant cohort (Kofman 2004, Kofman et al. 2000, Kofman, Saharso and Vacchelli 2013). Characterized at first as "an unintended consequence of the stoppage of mass labour migration in the 1970s" (Kofman 2004:248), the steady flow of dependent, primarily female, migrants from Muslim countries and the subsequent contestation over multiculturalism and the European identity have fueled 
debates on integration (Bonjour and de Hart 2013, Kofman, Saharso and Vacchelli 2013, Koopmans 2013, Lutz 1991). The multilayered and hardened pre-entry and post-arrival policies that many European countries began to impose on third-country family migrants were framed by a rhetoric promoting and facilitating immigrants' future incorporation, at times even by one championing gender equality and liberating Muslim women from oppression. As discerned by researchers studying these pre-entry and post-arrival measures (Block and Bonjour 2013, Grote 2017, Scholten et al. 2012, Strik et al. 2010), such restrictive policies are meant to verify the worthiness of these migrants and implemented to curb forced marriages and stem the flow of spousal migrants (Kofman, Saharso and Vacchelli 2013), often portrayed as lowly educated, submissive, and victimized Muslim women (Bonjour and de Hart 2013, Kofman et al. 2011, Kofman, Saharso and Vacchelli 2013, Razack 2004, Roggeband and Verloo 2007, Rostock and Berghahn 2008). This tendency to envisage marriage and family migrants as obedient, meek bodies and problematic groups that require emancipation was amplified and tackled by studies that elucidate the value-laden and boundary-drawing political, legal, and social responses to family migration (Bonjour and de Hart 2013, Bonjour and Kraler 2015, Razack 2004, Roggeband and Verloo 2007, Rostock and Berghahn 2008). Such a "homogenised image" (Kofman, Saharso and Vacchelli 2013:77), however, belies the heterogeneity that exists among female family migrants and obscures the reality that these women too have and can exercise agency throughout their migration process and bring expertise and professional knowledge into the receiving societies.

Yet another extreme at viewing female family migration, should it be liberated from the "vulnerable women trapped in migration" frame, is the propensity to downplay the challenges following voluntary and (partly) self-initiated migration. It is assumed that many of the same institutional hurdles and on-the-ground hardships facing family migrants have less effect on those blessed with a more sure-footed social position (i.e., higher skills, education, or socioeconomic status). While having the freedom and ability to embark on purposeful migration (in this case for marriage or family reunion) is nothing short of a prerogative, it by no means suggests that the journey to gain admission is less controlled. In fact, goaloriented migration is subject to minutely standardized prerequisites - often hidden from the public eye - just as well, which aptly captures the normative regime of family migration.

What is hardly mentioned is the indwelling paradox between "immaculately listed and contained" migration policies and the turbulent nature of tobe-immigrants' grappling with those demands. Between how destination countries envisage and sanitize migration in and through statutes and how active migrant agents live through the actual "move" are many missing pieces left to be located. Entry, for example, is just the beginning of the migratory process and experience. Whereas obtaining admission to the receiving country can be a daunting task involving much bureaucracy, the real hurdle of settling, rebuilding life, and positioning oneself in the host society-collective 
steps that can be encapsulated by "integrating" - is a whole other beast. With respect to how immigrants' post-arrival stage unfolds and how integration occurs, there are no fewer misconceptions. Conventional wisdom has it that migrants equipped with higher human capital will be able to orient themselves in the host-country labor market with relative ease, find positions commensurate with experiences and qualifications, and hence integrate better than those who are less or lowly skilled. This view, nevertheless, pertains chiefly to the imagery of an economic migrant. As the current political climate in Europe has made glaringly obvious, and for that matter also in Germany, integration is in essence, and always has been, a call to safeguard cultural heritage that has little to do with the economic dimension.

That is exactly what a third-country family migrant in Germany is expected to showcase - a strong willingness to integrate by attaining a basic level of German proficiency prior to entry - and adhere to - the obligation to attend integration courses that impart Germany's history, laws, politics, and core values and beliefs after arrival. For family migrants who are third-country nationals (a few exemptions apply; see Chapter 3 for details), their status comes with a clearly established perimeter, within which integration is not optional, but mandatory.

This nonetheless breeds and harbors reductionism. A reduction of behavior that the state may ordain where a family migrant sits for an entire year for the purpose of taking courses to ultimately integrate. A reduction of will and preferences that the state has the authority to actively prohibit an individual from undertaking other activities he or she deems more valuable. A reduction of standing that the state by wielding its rightful power tilts the balance in couple relationships and "unwittingly" places the migrant spouse in a weaker position. "Family migrant" seems enough of a category to unite all those labeled as such and rationalize reductionism when in reality the heterogeneity of its subjects precludes the possibility of their being "reduced" to a cohesive bunch.

The lurking peril of reductionism lies in the homogenization, even erasure, of family migrants' life histories (Kofman 1999:272). Aggregated as a group and bequeathed the same mission of integration, family migrants' past is indented and overshadowed by what they are to accomplish in the host country. Their foreseeable path and the parameters of their obligation to integrate are so standardly delineated given their shared status that it is as if what each has accumulated till the day before boarding the flight to Germany is, and can be, relegated to oblivion. However, how family migrants' postarrival trajectories evolve is contingent upon their pre-migration experiences. I was therefore propelled to investigate the less visible among the group, those who are highly educated and professionally qualified and do not neatly fit the stereotypical imagination of female family migrants, and to untangle how their well-rounded past blends into their future in Germany.

I see the principle of continuity as one vital element to comprehend and decipher the complexity and possible direction and developments of skilled family migrants' trajectories. Migration entails precipitous external changes 
and abrupt life transitions that could translate into prolonged internal adjustments. For skilled individuals who engaged in gainful employment before arriving as family migrants, it is the continuity of their employed status that is breached. As they carry traits of both qualified workers and spousal migrants, factoring in their attitudes toward work and family becomes indispensable to understanding how they perceive and approach the early post-arrival period.

While managing and harnessing the impact of work-related ruptures hover around primarily as the migrant's solitary battle with herself, the family sphere - shaped and underpinned by the constellation and dynamics of spousal migrants' binational and intercultural marriages - is a tango for two. As female family migrants enter Germany, their newly formed conjugal union or family setting becomes the most instrumental realm that tethers them to the host society and the focal point of their daily lives - a marked divergence from the experience of migrants who are single. Moreover, an often overlooked property of these unions that validate family reunification is how intercultural relationships as such to some degree parallel interactions between natives and foreigners, ergo adding a confounding component to intimacy and spousal migrants' ambit and process of acculturation.

This layer of constellation and its significance to skilled female family migrants' integration deserves closer scrutiny on two levels. First, the nativeforeigner dyad bespeaks a gap in both partners' experiences and disparate perspectives. Second, a dominant-population/minority-group configuration does not bode well for balanced intimacy. The truth is natives and immigrants - in this case intimate partners who are concurrently engulfed in the migration process - will most likely hold diametric views on the migratory experience and interpret post-arrival accommodation and its necessity differently. For one, knowledge of migration policies and details of their implementation is not a routine repertoire that natives retain. It is rather a need-based know-how, a learning-by-doing acquisition even for migrants themselves. As a result, I was surprised to find-during the preliminary stage of collecting clues for this project-that almost no Germans, sometimes not even fellow academics, are aware of the measures governing family migrants' entry. The few who are had firsthand encounters with the system through their partners, although their feedback as bystanders tends to concentrate on the functionality of policy mechanisms and rarely reflects the arduous migration trail itself. Equally obscure to native partners is the external pressure on family migrants to blend in. In fact, their being locals not only inhibits them from fully grasping their migrant spouses' struggles, but also explains their displaying native-centric tendencies that further compel their partners to conform to prevailing norms in the host society. Intimacy of equal footing in these intercultural marriages is hardly attainable in the face of the native partners' explicit cues or subconscious coaxing. Representative of the inherently antithetical positions that natives occupy vis-à-vis foreigners, these female family migrants' intercultural unions proffer a microcosm of societal tensions condensed at the household, dyad level. 
As illuminated thus far, I see the evident lacuna in a more comprehensive landscape of female family migration attributable to an expedient use of categories that scales down complexities and an oversight that many could and do straddle several categories. Classified crudely by their entry status as dependent migrants, these women are not differentiated by their educational attainment, skill composition, and occupational qualifications. Yet they are, and have been, professionally adept and active agents as well, who are now settled above all else in an intercultural family realm. How and whether they plan to "reconnect" with the German labor market, the fluctuation of their work commitment, and the development of their employment aspirations given their familial settings and how they approach the professional discontinuity is the crux of understanding their potentially "alternative" routes of integration. Researchers will not be able to extricate these skilled female family migrants' intricate post-arrival experiences without first acknowledging their situatedness in the family.

I hence set out to uncover what lies beneath the taken-for-granted integration trajectories by exploring Chinese-speaking skilled female family migrants' lived experiences during their early arrival period in Germany-otherwise entitled "immersion period" throughout this book. By targeting a migrant cohort that defies an express category or status and connotes blurred boundaries, I probe broadly how the immersion period affects skilled female family migrants' perceptions, self-conceptions, chances, and well-being in Germany, and zero in on how they respond to migration-triggered disruption of employment continuity. I dedicate this book to this often neglected group and hope to, in part, if not in full, render the invisible visible and problematize the unproblematic.

\section{Research overview}

This book is an inquiry into the stories of skilled female family migrants in Germany that are largely untold. Hinging on an ethnically homogeneous group from Taiwan and China, the study delves into the trajectories of female migrants who simultaneously bear traits of skilled and family migrants. In particular, I am intrigued by how interactions with the host society during their immersion period influence their self-conceptions, employment intentions, and aspirations.

I focus on a migrant population that straddles two categories to highlight how the two were often treated as mutually exclusive and the ambivalent attitudes the German government holds toward skilled female family migrants. On the one hand, Germany - the biggest economy in the European Union-joins the international talent hunt and hopes to retain and vie for skilled migrants. The language proficiency exemption carved out for spouses of holders of the EU Blue Card $^{1}$ - the residence permit reserved for highly qualified non-EU nationals - is a manifestation of an uncluttered migration scheme aimed at attracting brains. Nonetheless, the German government's lack of attention to and reactivation of female family migrants' skills contradicts their intention and efforts to lure 
talents. The sweeping stereotype of female family migrants as trailing wives has become so entrenched that they are rarely depicted as people previously engaged in the labor force, let alone skilled workers. On the other hand, the pre-admission screening instruments and the provision of integration courses to enhance immigrants' knowledge of German and the host society, while promoting spousal and dependent migrants' integration, unequivocally constrains and burdens family migrants.

The rather stringent entry hurdles for third-country nationals to join their spouses and the exceptions made to spouses of the highly skilled undoubtedly reflect Germany's predilection for skilled migrants in its immigration policies. Whether the society is equally welcoming to dependent migrants themselves, especially women, is, however, debatable. Germany has a long-standing tradition of providing family-oriented social welfare (Bussemaker and van Kersbergen, 1994), most notably for its childcare allowances and parental leave. These welfare policies are likely to affect women more than men for their role as mothers and have profound implications on women's participation in the labor market. The outdated term of "raven mother" in German once placed upon working mothers also discloses social expectations of intensive mothering and suggests a rigid gender role for women. As these welfare institutional arrangements and societal normative attitudes already deter German women's gainful employment, it is only logical to suspect similar, if not more unfavorable, conditions for female immigrants, even when they are skill bearers. Failure of female family migrants to take part in the workforce as a result of succumbing to external pressure, especially among the highly skilled, signifies a potential waste of talent and connotes forgoing an avenue to integration into the public sphere and German society, both unwanted and contradicting the government's efforts.

Germany's policies denote its attitude of embracing skilled migrants; its social welfare regime and traditional values are not facilitating women's entrance into the job market. Precisely when the much overlooked highly skilled female migrants are scrutinized do the above statements seem to be in conflict. Yet another facet that distinguishes this group of female family migrants is the dynamics of their intercultural marriage in the private sphere, where one partner is a native, the other an alien. Female family migrants' socialization in the host society takes place predominantly in the family realm and is heavily oriented toward their intimate partners. The attitudinal preferences and behavioral patterns of their German spouses therefore not only are reference anchors for these women, but also shape, mold, and even steer the direction of their acculturation. Thus, the gender-role attitudes and ideologies that the German husbands hold also affect skilled female migrants' employment decision-making. In other words, the German husbands can simultaneously be facilitators and gatekeepers during these female family migrants" "immersion period."

This study thus positions skilled female family migrants' post-arrival experience in the context of an externally imposed goal to integrate and the intercultural dynamics in the private sphere. It sets out to ascertain how they 
evaluate, adjust, and reconceive their circumstances in the host society. Furthermore, with an emphasis on temporal developments and processes throughout the immersion period - the decisive early post-arrival phase that remains opaque - rather than the "final outcomes" of their acculturation, this research seeks to understand how these female migrants eventually channel those assessments back to their employment intentions.

The scientific interests in exploring how skilled female family migrants view employment after arrival rest on three levels. First, at the individual level, it is worth investigating how these women alter their aspirations or life goals in the face of new gender and employment-related norms and values, and act subsequently. Second, as family migration, particularly spousal migration, necessitates sponsorship, there is a relationship of dependency between these women and their husbands. These women's subjective orientation toward work reciprocally influences and is predicated on the dyadic dynamics between partners. Third, deciphering the process of family migrants' early acculturation, how their views on employment change, and the value they attach to employment in the host society sheds light on the relationship between employment and family migrants' long-term integration.

\section{Research design and methodology}

The research focuses on the early immersion period of Chinese-speaking skilled female family migrants in Germany, specifically the transitions these women experience through the migration process, both physical and psychological, internal and external. It also explores how social constructs and societal norms in the host society steer or trigger such transitions through interactions and affect these female migrants' self-conceptions. These women's subjective work orientation (employment intentions) are consequently accounted for in association with their changing, changed, and challenged self-conceptions.

The core of the present enterprise is to elicit how these skilled female family migrants "subjectively" perceive themselves and their external environment. Thus, I employ qualitative methodologies where informants may narrate at length to best express themselves. In addition, the openness of qualitative methods also allows me, as a researcher, to attend to new concepts in the field and address them timely. To uncover and track changes during the post-arrival period, this project relies primarily on two waves of temporally progressive qualitative interviews with twenty female migrants. I also conducted supplementary interviews with seven German husbands, who shared observations on their wives' accommodation. Having obtained narratives from both sides in some married dyads facilitated my understanding of the early adaptation process from the angles of the "natives" and the "foreigners." The German spouses' input also vivifies the intercultural dynamics in the family sphere, a determining factor in skilled female migrants' post-arrival acculturation. 
Yet getting access to and recruiting newly arrived Chinese-speaking female family migrants in Germany has proven to be more wieldy and tortuous than imagined, which I deem warrants some additional explanations. The first part below enumerates in sequence the steps of and strategies for recruitment. In the second part, I offer a sketch of my sample. The third part delineates the formats of interviews and participant observation conducted between February 2016 and August 2017. I discuss subsequently the questions covered respectively in the two waves of migrant interviews and in spousal interviews.

\section{Recruitment process}

The target subjects of this research are highly skilled female migrants from Taiwan or China, referred to as "Chinese-speaking" in this book unless otherwise specified, who are married to German husbands. Restricting the sample to one ethnicity and two nationalities is a means to control for norms, values, cultural background, and ethnic upbringing. Despite historical linkages between these two countries, the polities of and political climate in the People's Republic of China and the Republic of China (Taiwan) cannot be further removed from each other. The former has been governed since 1949 by its Communist Party as a one-party state. The communist regime, while embracing a more disciplined version of capitalism, imposes draconian censorship rules on the country's media, publications, and internet to control its citizens. Taiwan, on the contrary, stands as the sole democracy in the Chinese-speaking world where citizens directly elect their president - every four years since 1996 - national legislators, and local representatives. Freedom of speech is also a fundamental right protected by the Constitution of the Republic of China. Such political divergences are not to be underestimated, for these political and legal configurations play a consequential part in citizens' home-country socialization and the molding of a nation's prevailing discourses. Yet, unlike a comparative study where female migrants from these two countries of origin are evenly represented, the purpose of this research is to scan the wider Chinese-speaking female family migrant community in Germany. In the process of comparing and contrasting individual cases, any noticeable or prominent elements related to home-country contexts will be teased out and appraised alongside other contextual factors.

As I intended to gain an early view of the adaptation process, the ideal informants were those who had arrived in Germany relatively recently, namely those either about to begin or having just started the obligatory one-year integration courses at the time of recruitment. In the meantime, I expected the selected sample to roughly reflect the distribution of migrant populations across regions and federal states and be geographically diverse. To meet these temporal and demographic criteria, I originally devised two recruitment plans: one through the corresponding government agency, the other through authorized integration course providers. Nonetheless, as advances via these paths fell short of expectations, I turned to active search and social networks for interview volunteers. 
I sought opportunities of cooperation and consultation from the Migration and Integration Research section at the Federal Office for Migration and Refugees (Bundesamt für Migration und Flüchtlinge, BAMF), the official body governing admission requirements, post-arrival settlement, and integration at the national level. BAMF maintains the Central Registers of Foreigners by collecting system-automated data nationwide from over 6000 local immigration authorities (Ausländerbehörden) (Bundesamt für Migration und Flüchtlinge 2017a). It also oversees the provision and implementation of integration courses by certified providers (e.g., religious organizations, private language institutes or academies, and community colleges). Gaining approval from BAMF would mean the research project's elevated visibility among local immigration offices, which in turn through their direct dealings with immigrants could boost effective recruitment.

BAMF's statistics on entitled and obligated integration course participation, on the other hand, show the density and distribution of course providers and attendees who are mostly early in their arrival. The data allow for an initial assessment of regions and districts where migrants concentrate. I then selected course providers in top-ranking metropolises (regional capitals) and identified four additional German conglomerates and major employers that are key "magnets" located outside of cities (i.e., BASF in Ludwigshafen, Merck Consumer in Darmstadt, Bayer in Leverkusen, and SAP in Walldorf) (Die Welt 2015, Forbes 2016), yielding a final list of ten sites (see Table 1.1).

Table 1.1 Final Ten Sites and Main Course Provider in the Area

\begin{tabular}{lll}
\hline City & Main Course Provider & Company On Site \\
\hline Darmstadt & VHS - Kulturinstitute der Stadt & Merck Consumer \\
Darmstadt & \\
Heidelberg & VHS Frankfurt am Main & \\
Karlsruhe & VHS Heidelberg & \\
Köln & Volkshochschule Karlsruhe & \\
Leverkusen & VHS der Stadt Köln Amt für & \\
Ludwigshafen am & Weiterbildung & Bayer \\
Rhein & VHS Leverkusen & BASF \\
München & Münchner Volkshochschule GmbH & \\
Stuttgart & VHS Stuttgart e.V. & \\
Walldorf & VHS Südliche Bergstraße e. V. & SAP \\
\hline
\end{tabular}

Source: Table compiled by author; data retrieved from Liste der zugelassenen Integrationskursträger (Bundesamt für Migration und Flüchtlinge 2017b).

Note: VHS or Volkshochschule are similar to community colleges that are dedicated to continued education. 
I respectively corresponded with BAMF's research unit and sent inquiry letters to course providers' contact persons, as listed in BAMF's registry between late 2015 and early 2016. Despite my proposal of passive recruitment, where no migrants would be actively approached and research recruitment leaflets distributed instead, the rather austere data-sharing and -protection policies were cited by BAMF's Section Head as the reasons why individual projects like mine were inadmissible. In addition, in the last three months of 2015, as the Syrian Civil War reached its apogee and caused an unprecedented influx of refugees fleeing to the European mainland, Germany was in the thick of accommodating daily new arrivals and saw an explosive surge in asylum seekers. As course providers were under massive pressure to cater to an increased number of integration-course attendees, all declined or were unable to assist my research project. Many course administrators hinted at obvious work overload and the lack of capacity to extend any form of support.

As initial plans failed to gain momentum, I began recruiting through active search on the internet and social media platforms by mid-January 2016. Active search entails scouting on Google for blogs and social platforms for postings containing pertinent traditional and simplified Chinese key terms, including integration courses (融合課), family reunification (家庭團聚), marriage migration (婚姻移民), and spouse migration (配偶移民).

It should be noted that, due to internet censorship in the People's Republic of China, Mainland Chinese are blocked from certain sites that are otherwise popular internationally, such as Facebook. Instead, they visit platforms exclusive to the Chinese-speaking community (e.g., Weibo), even when abroad. In Germany, dolc. de and kaiyuan.info are two such portals established mainly to serve overseas Chinese. On these two sites, threads and discussion boards covering all aspects of life in Germany are open to visitors; postings, however, require a validated user account.

Taiwanese, on the other hand, are accustomed to using Facebook. A wide spectrum of groups at the service of Taiwanese in Germany are available, yet more scattered and each with its own membership policies or guidelines for interaction. A Facebook account is the minimum prerequisite before one can access these groups. To engage or view threads in closed groups, those interested in joining are often requested by group administrators to submit a brief statement of intent and background description, which is the foundation for and facilitates membership approval. This minute screening process has become a common practice among many Taiwanese social groups on Facebook, allowing the administrators to match their target audience and fend off the ill-intentioned and possible exploitations of the groups.

I pinpointed twelve bulletins on the two Chinese sites and three Taiwanese Facebook groups for recruitment postings (see Table 1.2). I also initiated contact with bloggers who wrote about their experiences publicly, as well as users who posted or responded to questions on family migration and integration courses. The only hurdle - a minor nonetheless significant one - was entry into two of the Facebook groups (Taiwanese Wives Club and Child-rearing in Germany). In fact, my membership request was approved thanks to my married status and having a 
Table 1.2 List of Online Recruitment Bulletins and Groups

\begin{tabular}{ll}
\hline Platforms/Portal & List of Bulletin Boards and Groups \\
\hline dolc.de (萍聚社區) & Marriage \& Family \\
& German Language Forum \\
& Frankfurt \\
& Stuttgart \\
& Berlin \\
& Köln \\
Nordrhein-Westfalen \\
Practical Information \\
Mänchen \\
Freiburg \\
Nürnberg \\
Erlangen \\
Taiwanese Student Association in Germany \\
* Taiwanese Wives Club \\
* Child-rearing in Germany \\
\hline
\end{tabular}

Source: Table compiled by author.

Note: The selection criteria for bulletin boards are visitors' traffic (popularity) and number of total postings. Asterisks $\left(^{*}\right)$ denote a higher bar for group entry.

child. While I openly expressed to the administrators my research interest and intention to recruit interviewees via these platforms, my life profile and identities as a wife and a mother were decisive factors in my being accepted to these coteries. I will discuss my role as a "peripheral" insider in more detail in Chapter 5.

I posted recruitment notices tailored in both traditional and simplified Chinese on these forums and group pages between mid-February and early March 2016. As expatiated in the notice, desired research participants were expected to meet the following criteria: (1) Mandarin Chinese as mother tongue, (2) with a college/ university degree or above, (3) married to German husbands and came to Germany for family reunification, (4) currently enrolled in or about to commence integration courses, and (5) willing to take part in a research involving two chronological interviews on topics of post-migration adaption, experience, and employment intentions. I received four positive responses from bloggers and forum users I approached. Another 17 female family migrants through answering my posts on social media platforms and succeeding snowballing agreed to being interviewed (see Table 1.3). Toward the end of 2016, two more female migrants volunteered and signed up for the research, leading to a final total of twenty-three consented participants. Figure 1.1 is a flowchart that should crystallize the chronology of my recruitment schemes. 
16 Placing women in the migration context

Table 1.3 Confirmed Research Participants by Recruitment Method

\begin{tabular}{lclc}
\hline Means of Recruitment & \# of Taiwanese & $\begin{array}{l}\text { \# of Mainland } \\
\text { Chinese }\end{array}$ & $\begin{array}{c}\text { \# of Confirmed } \\
\text { Participants }\end{array}$ \\
\hline Active Search & 4 & 1 & 5 \\
Social Network & 9 & 5 & 14 \\
Postings & & & \\
Snowballing & 4 & 0 & 4 \\
Total & 17 & 6 & 23 \\
\hline
\end{tabular}

Source: Table compiled by author.

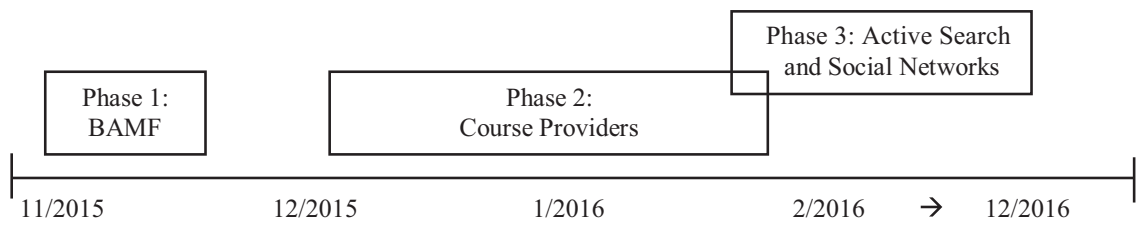

Figure 1.1 Timeline of Recruitment in Three Phases

\section{Sample}

Due to concerns about potential drop-outs in follow-up interviews and the significance of every case in a small sample, I adopted a rolling recruitment strategy. While the bulk of recruitment was carried out between January and March 2016, I later decided to include these female migrants' German spouses, wherever consent could be affirmed and retrieved, into the second-wave interviews. The final sample (see Table 1.4) consists of twenty-three female family migrants and seven German husbands. I discuss succinctly in the upcoming paragraphs the fluctuation of the sample, the demographics of the female family migrants, the reasons and principles behind recruiting the husbands, and potential sample selection bias.

Among the 23 female family migrants that confirmed their participation (with a signed consent form), 22 met the criteria of a qualified participant depicted previously. The actual count of respondents who completed both waves of interviews was nevertheless only 20. The three other informants respectively withdrew from the research during the first interview (Case 17, see Table 1.4), declined the second interview (Case 2), and did not entirely satisfy the conditions of a desired research object in this project (Case 23). Case 23, also a highly skilled female family migrant, came to Germany with her Taiwanese husband for his doctoral studies. The nationality of her spouse notwithstanding - the sole element that differentiates her from a "typical informant" in this study-her experience and story serve to contrast those of her counterparts with German spouses. I therefore welcomed this rather unexpected addition after she expressed interest in joining the research. 


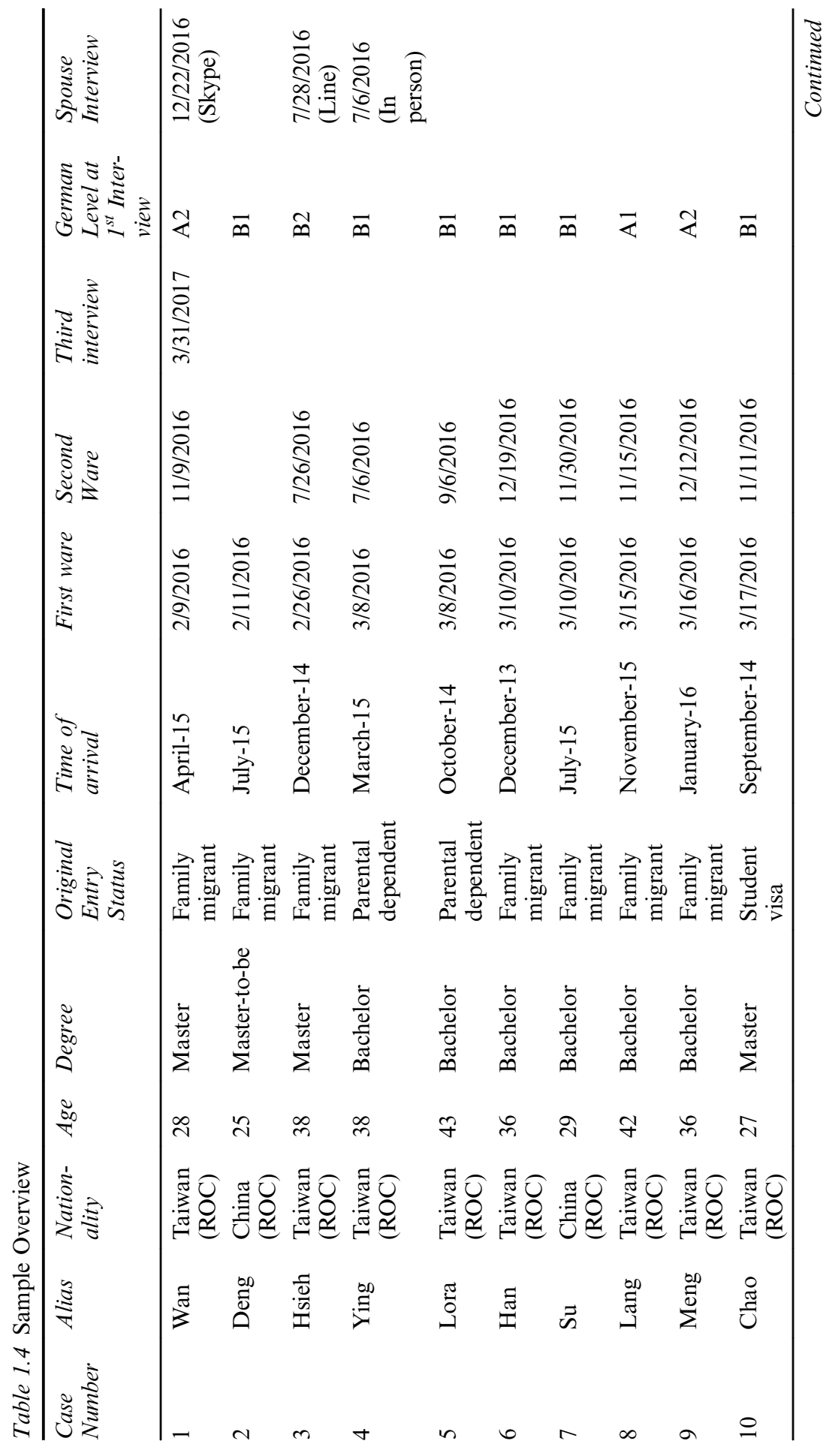




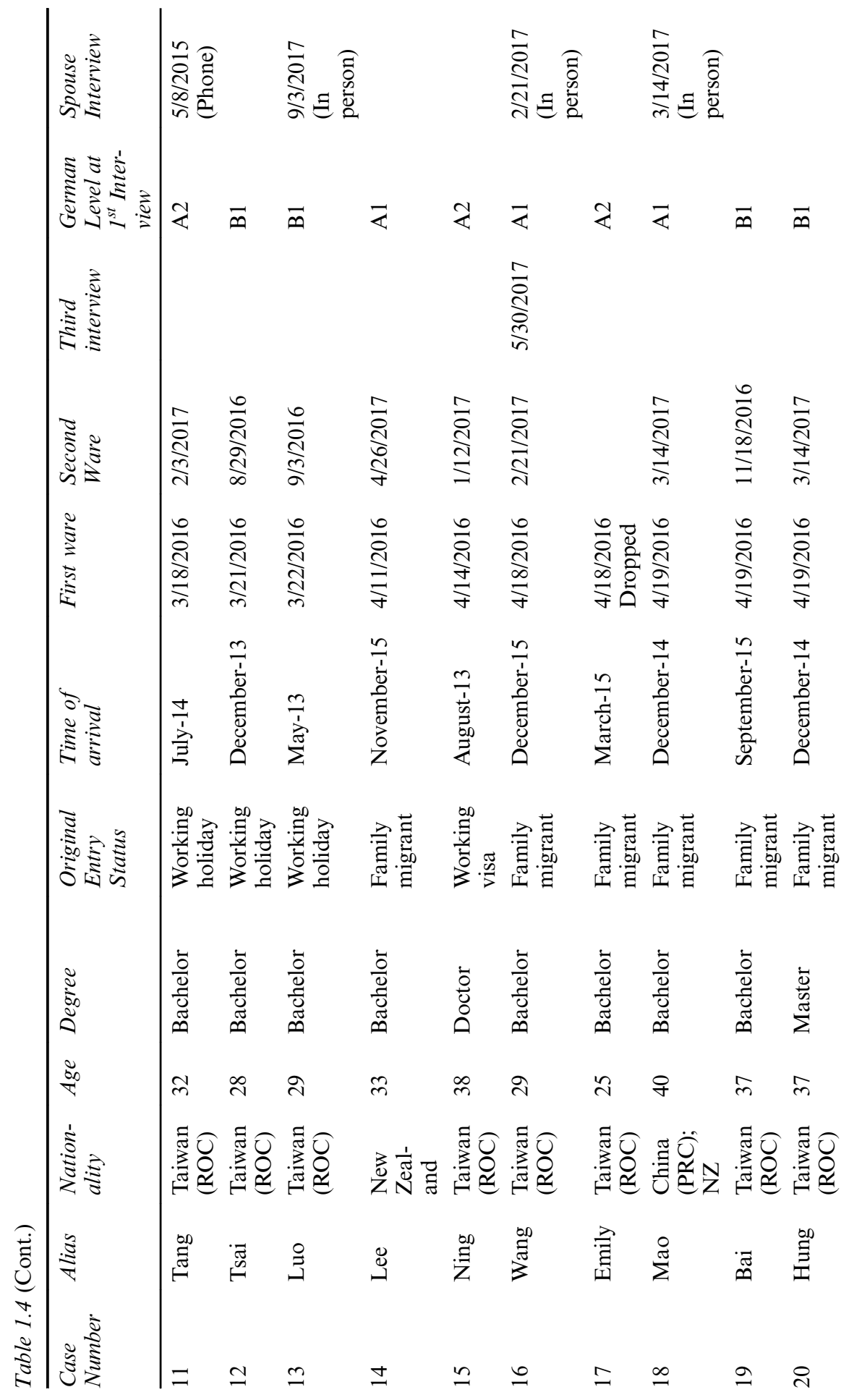




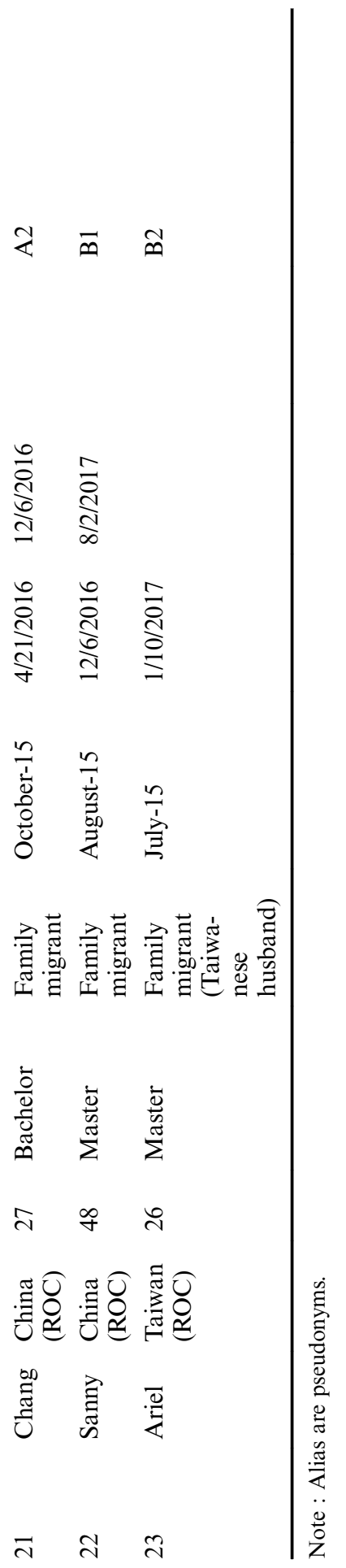




\section{Placing women in the migration context}

The majority of confirmed participants, 17, are from Taiwan (Republic of China). Two of the seven female migrants born and raised in Mainland China, or People's Republic of China, are of New Zealand citizenship or in possession of New Zealand's residence permit (Case 14 and 18). These women were between 25 and 48 years old, with the average age being 34 years old. Education wise, fifteen had a college or university education (bachelor's degree), six had a master's degree (two with foreign master's degree, one with an existing master's degree from Taiwan and pursuing another in Germany), one was about to complete her master's studies in Belgium, and one received a doctorate. Eight of them had more than ten years of working experience. With regards to their original entry status, sixteen of these women applied for entry as spousal migrants, two as parental dependents, three were on working holiday visas, one was on a student visa, and one was on a working visa for academic research. These 23 female family migrants were on average within 15 months of their arrival in Germany at our first encounter, 9 of them within 1 year. Only four informants (Case 6, 12, 13, and 14), three of them originally arriving for employment and working holidays, had stayed for over two years at that time. The participants resided in twenty cities and towns ${ }^{2}$ across Germany, spanning nine Federal states and balanced in the representation of metropolitan and rural scenes (see Figures 1.2 and 1.3).

The necessity to involve these female family migrants' German spouses surfaced soon after the first three or four interviews. It became manifest through these women's accounts that their German husbands were more than indispensable guarantors of entry. Many female migrants spoke of their husbands' sharing information, voicing opinions, and behavioral or attitudinal changes in the dyadic relationship. The notion that intercultural marriage dynamics and the role of German husbands could be instrumental to this research was gleaned from the field during first-wave interviews. Yet, I rely on these female migrants and their willingness to engage their partners, which called for deliberation and delicate handling. As these women are my primary research targets, how they feel, whether unequivocally articulated or latently hinted, in the existing couple dynamics is of paramount importance. To minimize the impact of my request in those dynamics and not compromise these women's standing in their marriages thus acted as my guiding principles. The request was raised to those female migrants who conveyed, according to my interpretation, no clear or irreconcilable tension or resistance in their couple dynamics during the first interview. Thereafter, those asked could choose whether they were inclined to relay the message. Altogether, I was able to recruit in this way seven German husbands, who agreed to participate as respondents at the beginning of my second-wave interviews (see Table 1.4).

\section{Data collection}

This research aims to track changes in female family migrants' self-conceptions in the early phase of their arrival in Germany. Critically, it 


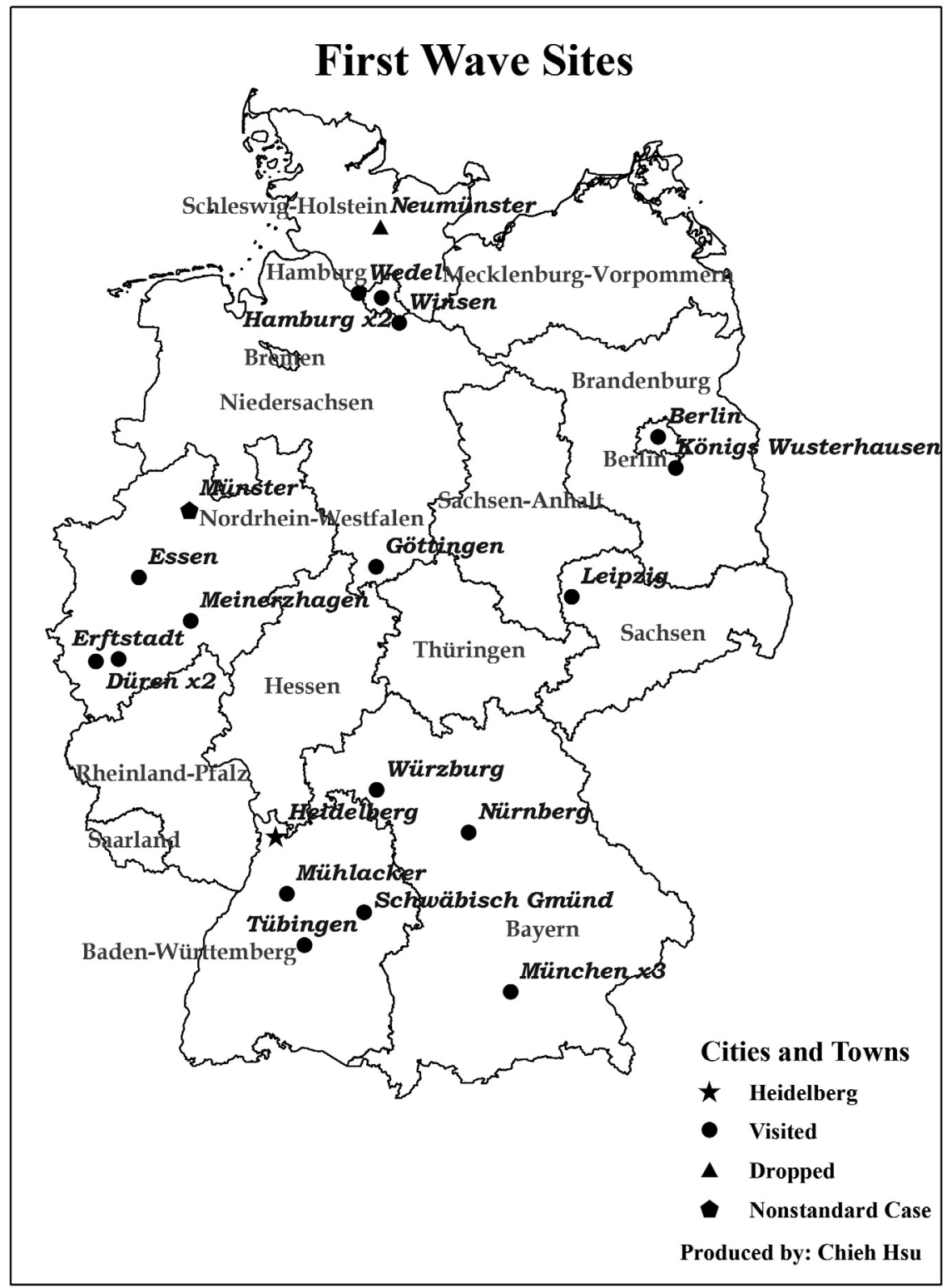

Figure 1.2 First Wave Distribution Map

examines how the pivotal family sphere and intercultural marriage dynamics in this immersion period contribute to their adaptation, with the goal of ultimately deciphering how female migrants conceive employment prospects in the host country. To grasp these transitions as time elapsed, I 


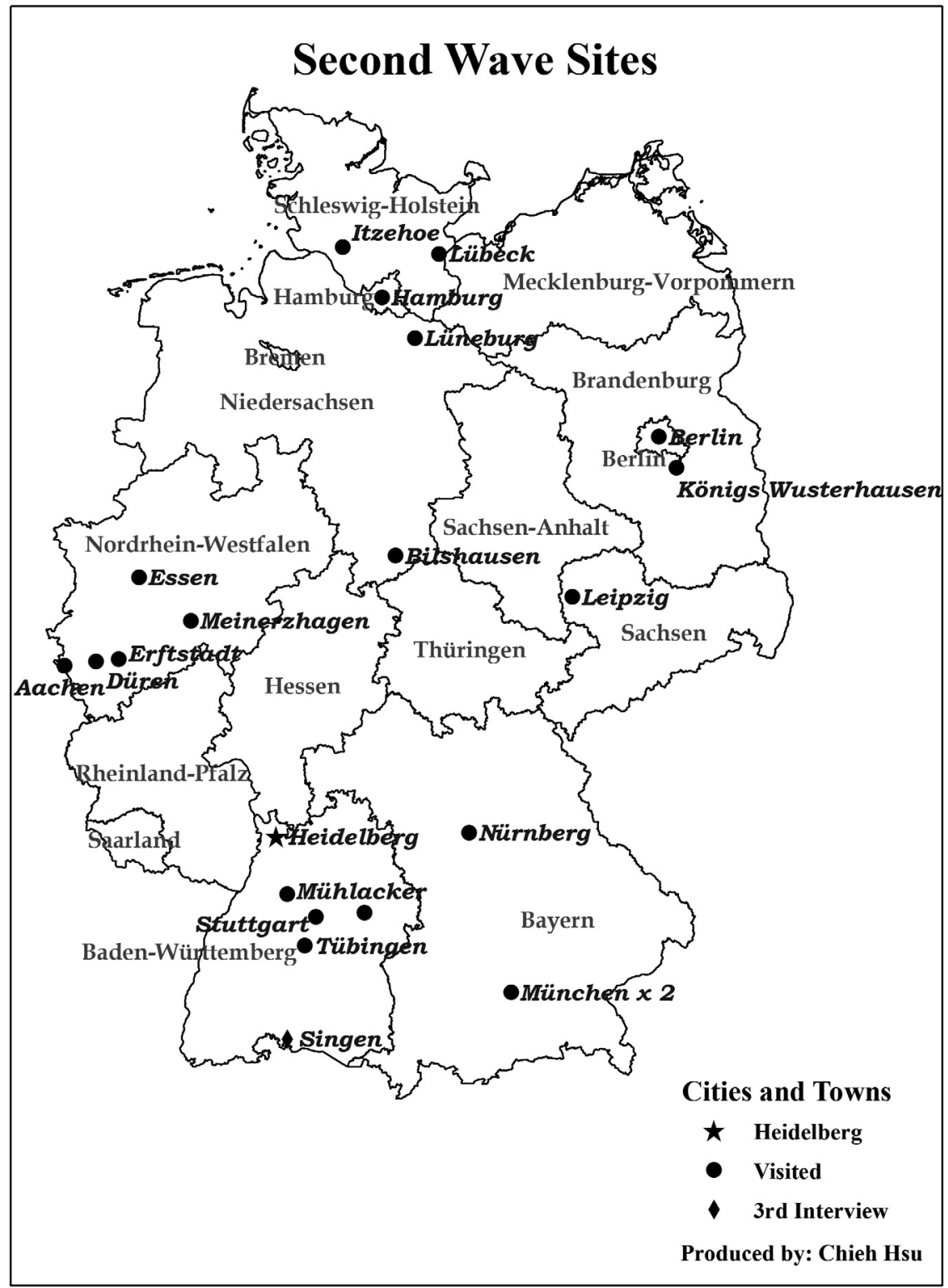

Figure 1.3 Second Wave Distribution Map

carried out two waves of longitudinal qualitative interviews between February 2016 and August 2017. The first interviews took place within four to twenty-eights months of these female migrants' arrival. An interval of five to twelve months followed before the second interviews, chiefly to allow 
for informants' progress with the integration courses. Excluding the "atypical" participant and withdrawals, I was able to complete this procedure individually with 20 qualified Chinese-speaking female family migrants. I also conducted interviews with seven German husbands within this period of time to understand how they view and evaluate their wives' acculturation. Beyond that, it was an attempt to piece together how such intercultural married dyads function. These interviews are additionally complemented by participant observation and contact history logs, on-site memos, and post-interview reports to document efforts involved before, during, and after the ethnographic work. I elucidate below some logistics and the design of both migrant and spousal interviews, the settings and content of my fieldwork, and the data gathered.

The qualitative semi-structured interviews with the female family migrants endeavored to capture (1) migrants' past socialization and homecountry experiences, (2) their respective migratory trajectory and experience, (3) hurdles faced due to (the lack of) language proficiency, (4) the nature of interactions between these women and their significant others in the family sphere, (5) if and how their self-conceptions change in the host society, and (6) how they conceive employment before and after arrival. Questions in the first interview are for the most part dedicated to migrants' socioeconomic background and life histories in the home country and early observations and perceptions of Germany. The second interview addressed more the temporal development, encompassing dimensions subject to change, such as language proficiency, couple dynamics, general perceptions and self-conceptions, and employment intentions. The semi-structured spousal interviews instead focused exclusively on the German husbands' role and observation throughout their wives' migration process and subsequent adaptation. They were also asked about how they foresaw their wives' employment prospects and potential working arrangements.

The fieldwork, stretching over one and a half years, brought me to 26 cities, towns, and villages across Germany. I visited every one of the twenty qualified respondents twice at their place of residence or the place most convenient to them. In two cases (see Table 1.4, Case 1 and 16), where one informant found a job and some previous interview statements required further elaboration of the other, a third interview was added. Our meetings took place in cafés at hotel lobbies, in corners of restaurants where exchanges would not be disturbed, or in the homes of the female family migrants. In scenarios where the respondents brought along their child, I administered interviews while strolling with the babies in the park or on a campus. On occasions where participants preferred staying at home for the interview, many offered me lunch or dinner, and I my assistance in the kitchen. I have had two such opportunities to dine with the informants' family. I spent about three to six hours with these female informants during our meet-up, often sharing meals, at times wandering in the city. Interviews with the female family migrants are 


\section{4}

Placing women in the migration context

conducted in our mother tongue-Mandarin Chinese. Nonetheless, when conversing with Mainland Chinese interviewees with heavier accents, I noticed some phrases and idioms formerly unknown to me. These, once resolved, did not obstruct the flow of the interviews. While I adhered faithfully to my guideline questions, I tried attending to new or unexpected concepts and probed deeper on casual cues brought up by the informants. The actual recordings themselves lasted on average eighty minutes, with the longest over two hours. The average length of second-wave interviews is 92 minutes compared to the first wave's average of 68 minutes. During the second wave of data collection, four inperson interviews with the German husbands immediately preceded or followed that with the female migrants, usually without the presence of their partners. The one exception was Case 16, where both partners preferred sitting through each other's interview. The remaining three spousal interviews were conducted via online communication systems or on the phone. Six spousal interviews were conducted in English, one in Chinese. These complementary interviews were significantly shorter, ranging from 14 minutes to 42 minutes and with an average of 29 minutes.

Besides recorded interviews, I kept separate on-site logs for each interview. Many valuable insights on and clues about their daily routine practices and language use in the host country can be gleaned from observing how female informants interact with their external environment. When both partners were present for the interview, tracking how they communicate with each other, body language, and certain rituals in private provided rich supplemental information about couple relationships and dynamics that are elusive and less substantiated in individual interviews. These notes were usually jotted down immediately during (when permissible) or after the session and served to augment the profile of each informant. All logs, memos, journals, and notes were written in English, as is consistent with the working language of this project.

In summary, the fieldwork of this project, comprised of qualitative semistructured interviews and participant observation, yielded 44 interviews with 22 female family migrants (42 interviews met the two-wave criterion) and 7 interviews with the German husbands. Total recording time is approximately 63 hours. I also compiled 44 on-site observation reports. I transcribed all interviews myself, respectively into Mandarin Chinese and English, and generated roughly 1200 pages of transcripts for analysis.

\section{Notes}

1 The EU Blue Card Directive governs the conditions of entry and residence of highly qualified non-EU nationals for the purpose of employment (EUR-Lex 2009).

2 Their places of residence might differ from the location where interviews were carried out. Three of the respondents moved to different locations between interviews. 


\section{References}

Aure, Marit. 2013. "Highly Skilled Dependent Migrants Entering the Labour Market: Gender and Place in Skill Transfer." Geoforum 45:277-286. doi:10.1016/j. geoforum.2012.11.015.

Bailey, Adrian J. and Thomas J. Cooke. 1998. "Family Migration and Employment: The Importance of Migration History and Gender." International Regional Science Review 21 (2):99-118. doi:10.1177/016001769802100201.

Block, Laura and Saskia Bonjour. 2013. "Fortress Europe or Europe of Rights? The Europeanisation of Family Migration Policies in France, Germany and the Netherlands." European Journal of Migration and Law 15 (2):203-224. doi:10.1163/15718166-12342031.

Bonjour, Saskia and Betty de Hart. 2013. "A Proper Wife, a Proper Marriage: Constructions of 'Us' and 'Them' in Dutch Family Migration Policy.” European Journal of Women's Studies 20 (1):61-76. doi:10.1177/1350506812456459.

Bonjour, Saskia and Albert Kraler. 2015. "Introduction: Family Migration as an Integration Issue? Policy Perspectives and Academic Insights." Journal of Family Issues 36 (11):1407-1432. doi:10.1177/0192513X14557490.

Boyle, Paul, Thomas J. Cooke, Keith Halfacree and Darren Smith. 2001. "A CrossNational Comparison of the Impact of Family Migration on Women's Employment Status.” Demography 38 (2):201-213. doi:10.1353/dem.2001.0012.

Bundesamt für Migration und Flüchtlinge, BAMF. 2017a. "Data Collection." Retrieved June 30, 2017 (http://www.bamf.de/EN/DasBAMF/Aufgaben/Datenerhe bung/datenerhebung-node.html).

Bundesamt für Migration und Flüchtlinge, BAMF. 2017b. "Liste der Zugelassenen Integrationskursträger.” Retrieved June 30, 2017 (http://www.bamf.de/SharedDocs/ Anlagen/DE/Downloads/Infothek/Integrationskurse/Kurstraeger/ListeKurstraeger/ liste-der-zugelassenen-kurstraeger-pdf.html.)

Bussemaker, Jet and Kees van Kersbergen. 1994. "Gender and Welfare States: Some Theoretical Reflections.” Pp. 8-25 in Gendering Welfare States, edited by D. Sainsbury. London; Thousand Oaks, Calif.: SAGE Publications Ltd.

Castles, Stephen and Mark J. Miller. 2009. The Age of Migration: International Population Movements in the Modern World. New York: Guilford Press.

Catarino, C. and M. Morokvasic. 2013. "Women, Gender, Transnational Migrations and Mobility: Focus on Research in France." Pp. 246-267 in International Handbook on Gender, Migration and Transnationalism: Global and Development Perspectives, edited by Laura Oso and Natalia Ribas Mateos. Cheltenham, UK; Massachusetts: Edward Elgar Publishing. doi:10.4337/9781781951477.

Die Welt. 2015. "Die 500 größten Unternehmen in Deutschland: Rangliste von 1 bis 50.” Retrieved January 8, 2016 (http://top500.welt.de/search).

Docquier, F., B. L. Lowell and A. Marfouk. 2009. "A Gendered Assessment of Highly Skilled Emigration." Population and Development Review 35 (2):297-321. doi:10.1111/j.1728-4457.2009.00277.x.

Docquier, Frédéric, Abdeslam Marfouk, Sara Salomone and Khalid Sekkat. 2012. "Are Skilled Women More Migratory Than Skilled Men?" World Development 40 (2):251-265. doi: https://doi.org/10.1016/j.worlddev.2011.05.004.

EUR-Lex. 2009. "Council Directive 2009/50/EC of 25 May 2009 on the Conditions of Entry and Residence of Third-Country Nationals for the Purposes of Highly Qualified Employment." Retrieved December 28, 2016 (http://data.europa.eu/eli/dir/ 2009/50/oj). 


\section{Placing women in the migration context}

Forbes. 2016. “The World's Biggest Public Companies. Country: Germany.” Retrieved January 8, 2016 (https://www.forbes.com/global2000/list/\#country:Germany).

Grote, Janne. 2017. "Family Reunification of Third-Country Nationals in Germany." Working Paper 73 of the Research Centre of the Federal Office for Migration and Refugees. Federal Office for Migration and Refugees, Nuremberg.

Ho, Christina. 2006. "Women Crossing Borders: The Changing Identities of Professional Chinese Migrant Women in Australia." PORTAL Journal of Multidisciplinary International Studies 3 (2). doi:10.5130/portal.v3i2.140.

Iredale, R. 2005. "Gender Immigration Policies and Accreditation: Valuing the Skills of Professional Women Migrants." Geoforum 36 (2):155-166. doi:10.1016/j. geoforum.2004.04.002.

Jakobsen, Vibeke and Anika Liversage. 2017. "From Work to Welfare: Institutional Arrangements Shaping Turkish Marriage Migrants' Gendered Trajectories into a New Society." International Migration Review 51 (4):964-998. doi:10.1111/imre.12264.

King, Russell. 2002. "Towards a New Map of European Migration." International Journal of Population Geography 8 (2):89-106. doi:10.1002/ijpg.246.

Kofman, Eleonore. 1999. "Female 'Birds of Passage' a Decade Later: Gender and Immigration in the European Union.” International Migration Review 33 (2):269-299. doi: $10.2307 / 2547698$.

Kofman, Eleonore. 2000. "The Invisibility of Skilled Female Migrants and Gender Relations in Studies of Skilled Migration in Europe." International Journal of Population Geography 6 (1):45-59.

Kofman, Eleonore. 2004. "Family-Related Migration: A Critical Review of European Studies." Journal of Ethnic and Migration Studies 30 (2):243-262. doi:10.1080/ 1369183042000200687.

Kofman, Eleonore, Annie Phizacklea, Parvati Raghuram and Rosemary Sales. 2000. Gender and International Migration in Europe: Employment, Welfare, and Politics. London; New York: Routledge.

Kofman, Eleonore, Albert Kraler, Martin Kohli and Camille Schmoll. 2011. "Introduction: Issues and Debates on Family-Related Migration and the Migrant Family: A European Perspective." Pp. 13-54 in Gender, Generations and the Family in International Migration, edited by A. Kraler, E. Kofman, M. Kohli and C. Schmoll. Amsterdam: Amsterdam University Press.

Kofman, Eleonore, Sawitri Saharso and Elena Vacchelli. 2013. "Gendered Perspectives on Integration Discourses and Measures." International Migration 53 (4):77-89. doi:10.1111/imig.12102.

Koopmans, Ruud. 2013. "Multiculturalism and Immigration: A Contested Field in Cross-National Comparison." Annual Review of Sociology 39 (1):147-169. doi:10.1146/annurev-soc-071312-145630.

Koser, Khalid and John Salt. 1997. "The Geography of Highly Skilled International Migration." International Journal of Population Geography 3 (4):285-303. doi:10.1002/(SICI)1099-1220(199712)3:4-285:AID-IJPG72-3.0.CO;2-W.

Liversage, Anika. 2009a. "Vital Conjunctures, Shifting Horizons: High-Skilled Female Immigrants Looking for Work." Work Employment and Society 23 (1):120-141. doi:10.1177/0950017008099781.

Liversage, Anika. 2009b. "Finding a Path: Investigating the Labour Market Trajectories of High-Skilled Immigrants in Denmark." Journal of Ethnic and Migration Studies 35 (2):203-226. doi:10.1080/13691830802586195. 
Lutz, Helma. 1991. "The Myth of the 'Other': Western Representation and Images of Migrant Women of So Called 'Islamic Background'." International Review of Sociology 2 (2):121-137. doi:10.1080/03906701.1991.9971091.

Man, Guida. 2004. "Gender, Work and Migration: Deskilling Chinese Immigrant Women in Canada.” Women's Studies International Forum 27 (2):135-148. http:// dx.doi.org/10.1016/j.wsif.2004.06.004.

Meares, C. 2010. "A Fine Balance: Women, Work and Skilled Migration." Women's Studies International Forum 33 (5):473-481. doi:10.1016/j.wsif.2010.06.001.

Mollard, Blandine and Jason Gagnon, eds. 2014. Harnessing Knowledge on the Migration of Highly Skilled Women. Geneva, Switzerland: International Organization for Migration (IOM).

Morokvasic, M. 1984. "Birds of Passage Are Also Women." International Migration Review 18 (4):886-907. doi:10.2307/2546066.

Purkayastha, Bandana. 2005. "Skilled Migration and Cumulative Disadvantage: The Case of Highly Qualified Asian Indian Immigrant Women in the US." Geoforum 36 (2):181-196. http://dx.doi.org/10.1016/j.geoforum.2003.11.006.

Raghuram, Parvati. 2004. "The Difference That Skills Make: Gender, Family Migration Strategies and Regulated Labour Markets." Journal of Ethnic \& Migration Studies 30 (2):303-321. doi:10.1080/1369183042000200713.

Razack, Sherene H. 2004. "Imperilled Muslim Women, Dangerous Muslim Men and Civilised Europeans: Legal and Social Responses to Forced Marriages." Feminist Legal Studies 12 (2):129-174. doi:10.1023/B:FEST.0000043305.66172.92.

Riaño, Yvonne. 2011. “'He's the Swiss Citizen, I'm the Foreign Spouse': Binational Marriages and the Impact of Family-Related Migration Policies on Gender Relations." Pp. 265-284 in Gender, Generations and the Family in International Migration. Amsterdam: Amsterdam University Press.

Riaño, Yvonne. 2014. "Highly Skilled Migrant Women: Dual-Career Households, Family Considerations and Gender Roles." Pp. 77-85 in Harnessing Knowledge on the Migration of Highly Skilled Women, edited by B. Mollard and J. Gagnon. Geneva, Switzerland: International Organization for Migration (IOM).

Riaño, Yvonne. 2015. "Latin American Women Who Migrate for Love: Imagining European Men as Ideal Partners." Pp. 45-60 in Rethinking Romantic Love: Discussions, Imaginaries and Practices, edited by B. Enguix and J. Roca. Newcastle upon Tyne, UK: Cambridge Scholars Publishing.

Roggeband, C. and M. Verloo. 2007. "Dutch Women Are Liberated, Migrant Women Are a Problem: The Evolution of Policy Frames on Gender and Migration in the Netherlands, 1995-2005." Social Policy \& Administration 41 (3):271-288. doi:10.1111/ j.1467-9515.2007.00552.x.

Rostock, P. and S. Berghahn. 2008. "The Ambivalent Role of Gender in Redefining the German Nation.” Ethnicities 8 (3):345-364. doi:10.1177/1468796808092447.

Salt, John. 1992. "Migration Processes among the Highly Skilled in Europe." The International Migration Review 26 (2):484-505. doi:10.2307/2547068.

Scholten, P., Han Entzinger, Christina Holloney, Eleonore Kofman and Claudia Lechner. 2012. "Integration from Abroad? Perception and Impacts of Pre-Entry Tests for Third Country Nationals." WP4 PROSINCT Comparative Reports. Vienna: ICMPD.

Strik, Tineke, Anita Böcker, Maaike Luiten and Ricky van Oers. 2010. "Integration and Naturalisation Tests: The New Way to European Citizenship. A Comparative Study in Nine Member States on the National Policies Concerning Integration and 
28 Placing women in the migration context

Naturalisation Tests and Their Effects on Integration." The INTEC Project: Draft Synthesis Report. Nijmegen: Centre for Migration Law, Radboud University Nijmegen.

Yeoh, Brenda S. A. and Katie Willis. 2005. "Singaporeans in China: Transnational Women Elites and the Negotiation of Gendered Identities." Geoforum 36 (2):211222. https://doi.org/10.1016/j.geoforum.2003.07.004.

Zlotnik, H. 1990. "International Migration Policies and the Status of Female Migrants.” International Migration Review 24 (2):372-381. doi:10.2307/2546556.

Zlotnik, H. 1995. "The South-to-North Migration of Women." International Migration Review 29 (1):229-254. doi:10.2307/2547003. 


\section{Notes}

\section{Chapter 1}

1 The EU Blue Card Directive governs the conditions of entry and residence of highly qualified non-EU nationals for the purpose of employment (EUR-Lex 2009).

2 Their places of residence might differ from the location where interviews were carried out. Three of the respondents moved to different locations between interviews.

\section{Chapter 2}

1 Data derived from "Abbildung 5-16: Höchster allgemeinbildender Schulabschluss nach Teilgruppen und in Gesamtbevölkerung in Deutschland (in Prozent)." (Büttner and Stichs 2014.) Final percentage of female spousal migrants' highest secondary school education calculated by author.

2 These are: Turkey, Bosnia and Herzegovina, Serbia, Montenegro, Macedonia, Ukraine, Russia, India, Pakistan, the Philippines, and Thailand. See ibid.

3 Data derived from "Abbildung 5-17: Höchster beruflicher Bildungsabschluss nach Teilgruppen (in Prozent)." Ibid. Final percentage of female spousal migrants' highest educational attainment and training calculated by author.

4 See "Abbildung 4-5: Paarkonstellationen in Bezug auf die Herkunft nach Teilgruppen (in Prozent)." Ibid.

5 See Tabelle 4-3: Altersabstand zum Partner nach Teilgruppen (in Prozent, im Durchschnitt). Ibid.

\section{Chapter 3}

1 The structure of the current integration courses is specified in the 2016 Integration Act (Integrationsgesetz) (Grote 2017).

2 See "Abbildung 5-23: Art der Erwerbstätigkeit nach Teilgruppen (in Prozent)" (Büttner and Stichs 2014).

3 See "Abbildung 5-25: Arbeitszeitmodell nach Geschlecht (in Prozent)" (ibid).

4 Residence titles issued for the employment of qualified foreign workers pursuant to Section 18 of the Residence Act (Aufenthaltsgesetz) are to be distinguished from EU Blue Cards, which are distributed among highly skilled third-country nationals who are to take up qualified employment in Germany. The issuance of the latter is regulated by Section 19a of the Residence Act. See Bundesministerium der Justiz und für Verbraucherschutz, BMJV (2016a). 
5 Science, Technology, Engineering, and Mathematics. The German equivalent of STEM subjects are MINT (Mathematik, Informatik, Naturwissenschaft, und Technik) specializations.

6 See Bayerisches Staatsministerium für Familie, Arbeit und Soziales, StMAS Bayern (2017). Family care contribution (Betreuungsgeld) is scheduled to be replaced by a comprehensive family subsidy (Familiengeld) under the Bavarian Minister-President Söder. See Bayerische Staatszeitung, BSZ (2018).

\section{Chapter 4}

1 As FitzGerald (2015) suggests, while the concept of assimilation was more limited to the United States and later replaced with the more neutral "integration," the distinction between integration and assimilation has been blurred; both terms are used rather interchangeably today depending on "political preferences and academic socialization in particular national contexts" (p. 118).

\section{Chapter 6}

1 Mutual interdependency is envisioned to be a more balanced relationship where dependency, if any, is established on individual choice and volition. The malebreadwinner and female-caretaker model is an example of gendered division of labor in intimate relationships where women's domestic role, subsequently their dependency, is favored and opted for. In this case, female dependency is the result of voluntary arrangements and a byproduct of mutual interdependency (based on the principle of complementarity between partners or spouses). I use asymmetrical dependency mainly to reflect that the dependency experienced in female family migrants' intercultural marriages is atypical, imposed, and undesired by many informants.

2 As I conducted interviews in English with all but one German husbands, the citations included here are their original and transcribed utterances.

\section{Chapter 7}

1 It might be appropriate to evoke the notion of "true selves" formulated by Charles and Bradley (2009:929) as a comparison. True selves indicate a somewhat counterintuitive conjuncture of self-expression and subconscious gender conformity. That is, self-realization is done while affirming underlying and prescribed gender scripts or conventions. 


\section{References}

Aure, Marit. 2013. "Highly Skilled Dependent Migrants Entering the Labour Market: Gender and Place in Skill Transfer." Geoforum 45:277-286. doi:10.1016/j. geoforum.2012.11.015.

Bailey, Adrian J. and Thomas J. Cooke. 1998. "Family Migration and Employment: The Importance of Migration History and Gender." International Regional Science Review 21 (2):99-118. doi:10.1177/016001769802100201.

Block, Laura and Saskia Bonjour. 2013. "Fortress Europe or Europe of Rights? The Europeanisation of Family Migration Policies in France, Germany and the Netherlands." European Journal of Migration and Law 15 (2):203-224. doi:10.1163/15718166-12342031.

Bonjour, Saskia and Betty de Hart. 2013. "A Proper Wife, a Proper Marriage: Constructions of 'Us' and 'Them' in Dutch Family Migration Policy.” European Journal of Women's Studies 20 (1):61-76. doi:10.1177/1350506812456459.

Bonjour, Saskia and Albert Kraler. 2015. "Introduction: Family Migration as an Integration Issue? Policy Perspectives and Academic Insights." Journal of Family Issues 36 (11):1407-1432. doi:10.1177/0192513X14557490.

Boyle, Paul, Thomas J. Cooke, Keith Halfacree and Darren Smith. 2001. "A CrossNational Comparison of the Impact of Family Migration on Women's Employment Status.” Demography 38 (2):201-213. doi:10.1353/dem.2001.0012.

Bundesamt für Migration und Flüchtlinge, BAMF. 2017a. "Data Collection." Retrieved June 30, 2017 (http://www.bamf.de/EN/DasBAMF/Aufgaben/Datenerhe bung/datenerhebung-node.html).

Bundesamt für Migration und Flüchtlinge, BAMF. 2017b. "Liste der Zugelassenen Integrationskursträger.” Retrieved June 30, 2017 (http://www.bamf.de/SharedDocs/ Anlagen/DE/Downloads/Infothek/Integrationskurse/Kurstraeger/ListeKurstraeger/ liste-der-zugelassenen-kurstraeger-pdf.html.)

Bussemaker, Jet and Kees van Kersbergen. 1994. "Gender and Welfare States: Some Theoretical Reflections." Pp. 8-25 in Gendering Welfare States, edited by D. Sainsbury. London; Thousand Oaks, Calif: SAGE Publications Ltd.

Castles, Stephen and Mark J. Miller. 2009. The Age of Migration: International Population Movements in the Modern World. New York: Guilford Press.

Catarino, C. and M. Morokvasic. 2013. "Women, Gender, Transnational Migrations and Mobility: Focus on Research in France." Pp. 246-267 in International Handbook on Gender, Migration and Transnationalism: Global and Development Perspectives, edited by Laura Oso and Natalia Ribas Mateos. Cheltenham, UK; Massachusetts: Edward Elgar Publishing. doi:10.4337/9781781951477. 
Die Welt. 2015. "Die 500 größten Unternehmen in Deutschland: Rangliste von 1 bis 50.” Retrieved January 8, 2016 (http://top500.welt.de/search).

Docquier, F., B. L. Lowell and A. Marfouk. 2009. "A Gendered Assessment of Highly Skilled Emigration.” Population and Development Review 35 (2):297-321. doi:10.1111/j.1728-4457.2009.00277.x.

Docquier, Frédéric, Abdeslam Marfouk, Sara Salomone and Khalid Sekkat. 2012. “Are Skilled Women More Migratory Than Skilled Men?" World Development 40 (2):251-265. doi: https://doi.org/10.1016/j.worlddev.2011.05.004.

EUR-Lex. 2009. "Council Directive 2009/50/EC of 25 May 2009 on the Conditions of Entry and Residence of Third-Country Nationals for the Purposes of Highly Qualified Employment." Retrieved December 28, 2016 (http://data.europa.eu/eli/dir/ 2009/50/oj).

Forbes. 2016. "The World's Biggest Public Companies. Country: Germany." Retrieved January 8, 2016 (https://www.forbes.com/global2000/list/\#country:Germany).

Grote, Janne. 2017. "Family Reunification of Third-Country Nationals in Germany." Working Paper 73 of the Research Centre of the Federal Office for Migration and Refugees. Federal Office for Migration and Refugees, Nuremberg.

Ho, Christina. 2006. "Women Crossing Borders: The Changing Identities of Professional Chinese Migrant Women in Australia." PORTAL Journal of Multidisciplinary International Studies 3 (2). doi:10.5130/portal.v3i2.140.

Iredale, R. 2005. "Gender Immigration Policies and Accreditation: Valuing the Skills of Professional Women Migrants." Geoforum 36 (2):155-166. doi:10.1016/j. geoforum.2004.04.002.

Jakobsen, Vibeke and Anika Liversage. 2017. "From Work to Welfare: Institutional Arrangements Shaping Turkish Marriage Migrants' Gendered Trajectories into a New Society." International Migration Review 51 (4):964-998. doi:10.1111/imre.12264.

King, Russell. 2002. "Towards a New Map of European Migration.” International Journal of Population Geography 8 (2):89-106. doi:10.1002/ijpg.246.

Kofman, Eleonore. 1999. "Female 'Birds of Passage' a Decade Later: Gender and Immigration in the European Union.” International Migration Review 33 (2):269-299. doi: $10.2307 / 2547698$.

Kofman, Eleonore. 2000. "The Invisibility of Skilled Female Migrants and Gender Relations in Studies of Skilled Migration in Europe." International Journal of Population Geography 6 (1):45-59.

Kofman, Eleonore. 2004. "Family-Related Migration: A Critical Review of European Studies." Journal of Ethnic and Migration Studies 30 (2):243-262. doi:10.1080/ 1369183042000200687.

Kofman, Eleonore, Annie Phizacklea, Parvati Raghuram and Rosemary Sales. 2000. Gender and International Migration in Europe: Employment, Welfare, and Politics. London; New York: Routledge.

Kofman, Eleonore, Albert Kraler, Martin Kohli and Camille Schmoll. 2011. "Introduction: Issues and Debates on Family-Related Migration and the Migrant Family: A European Perspective." Pp. 13-54 in Gender, Generations and the Family in International Migration, edited by A. Kraler, E. Kofman, M. Kohli and C. Schmoll. Amsterdam: Amsterdam University Press.

Kofman, Eleonore, Sawitri Saharso and Elena Vacchelli. 2013. "Gendered Perspectives on Integration Discourses and Measures." International Migration 53 (4):77-89. doi:10.1111/imig.12102. 
Koopmans, Ruud. 2013. "Multiculturalism and Immigration: A Contested Field in Cross-National Comparison.” Annual Review of Sociology 39 (1):147-169. doi:10.1146/annurev-soc-071312-145630.

Koser, Khalid and John Salt. 1997. "The Geography of Highly Skilled International Migration." International Journal of Population Geography 3 (4):285-303. doi:10.1002/(SICI)1099-1220(199712)3:4-285:AID-IJPG72-3.0.CO;2-W.

Liversage, Anika. 2009a. "Vital Conjunctures, Shifting Horizons: High-Skilled Female Immigrants Looking for Work." Work Employment and Society 23 (1):120-141. doi:10.1177/0950017008099781.

Liversage, Anika. 2009b. "Finding a Path: Investigating the Labour Market Trajectories of High-Skilled Immigrants in Denmark." Journal of Ethnic and Migration Studies 35 (2):203-226. doi:10.1080/13691830802586195.

Lutz, Helma. 1991. "The Myth of the 'Other': Western Representation and Images of Migrant Women of So Called 'Islamic Background'." International Review of Sociology 2 (2):121-137. doi:10.1080/03906701.1991.9971091.

Man, Guida. 2004. "Gender, Work and Migration: Deskilling Chinese Immigrant Women in Canada." Women's Studies International Forum 27 (2):135-148. http:// dx.doi.org/10.1016/j.wsif.2004.06.004.

Meares, C. 2010. "A Fine Balance: Women, Work and Skilled Migration.” Women's Studies International Forum 33 (5):473-481. doi:10.1016/j.wsif.2010.06.001.

Mollard, Blandine and Jason Gagnon, eds. 2014. Harnessing Knowledge on the Migration of Highly Skilled Women. Geneva, Switzerland: International Organization for Migration (IOM).

Morokvasic, M. 1984. "Birds of Passage Are Also Women." International Migration Review 18 (4):886-907. doi:10.2307/2546066.

Purkayastha, Bandana. 2005. "Skilled Migration and Cumulative Disadvantage: The Case of Highly Qualified Asian Indian Immigrant Women in the US." Geoforum 36 (2):181-196. http://dx.doi.org/10.1016/j.geoforum.2003.11.006.

Raghuram, Parvati. 2004. "The Difference That Skills Make: Gender, Family Migration Strategies and Regulated Labour Markets." Journal of Ethnic \& Migration Studies 30 (2):303-321. doi:10.1080/1369183042000200713.

Razack, Sherene H. 2004. "Imperilled Muslim Women, Dangerous Muslim Men and Civilised Europeans: Legal and Social Responses to Forced Marriages." Feminist Legal Studies 12 (2):129-174. doi:10.1023/B:FEST.0000043305.66172.92.

Riaño, Yvonne. 2011. “He's the Swiss Citizen, I'm the Foreign Spouse': Binational Marriages and the Impact of Family-Related Migration Policies on Gender Relations." Pp. 265-284 in Gender, Generations and the Family in International Migration. Amsterdam: Amsterdam University Press.

Riaño, Yvonne. 2014. "Highly Skilled Migrant Women: Dual-Career Households, Family Considerations and Gender Roles.” Pp. 77-85 in Harnessing Knowledge on the Migration of Highly Skilled Women, edited by B. Mollard and J. Gagnon. Geneva, Switzerland: International Organization for Migration (IOM).

Riaño, Yvonne. 2015. "Latin American Women Who Migrate for Love: Imagining European Men as Ideal Partners." Pp. 45-60 in Rethinking Romantic Love: Discussions, Imaginaries and Practices, edited by B. Enguix and J. Roca. Newcastle upon Tyne, UK: Cambridge Scholars Publishing.

Roggeband, C. and M. Verloo. 2007. "Dutch Women Are Liberated, Migrant Women Are a Problem: The Evolution of Policy Frames on Gender and Migration in the 
Netherlands, 1995-2005." Social Policy \& Administration 41 (3):271-288. doi:10.1111/ j.1467-9515.2007.00552.x.

Rostock, P. and S. Berghahn. 2008. "The Ambivalent Role of Gender in Redefining the German Nation.” Ethnicities 8 (3):345-364. doi:10.1177/1468796808092447.

Salt, John. 1992. "Migration Processes among the Highly Skilled in Europe." The International Migration Review 26 (2):484-505. doi:10.2307/2547068.

Scholten, P., Han Entzinger, Christina Holloney, Eleonore Kofman and Claudia Lechner. 2012. "Integration from Abroad? Perception and Impacts of Pre-Entry Tests for Third Country Nationals." WP4 PROSINCT Comparative Reports. Vienna: ICMPD.

Strik, Tineke, Anita Böcker, Maaike Luiten and Ricky van Oers. 2010. "Integration and Naturalisation Tests: The New Way to European Citizenship. A Comparative Study in Nine Member States on the National Policies Concerning Integration and Naturalisation Tests and Their Effects on Integration." The INTEC Project: Draft Synthesis Report. Nijmegen: Centre for Migration Law, Radboud University Nijmegen.

Yeoh, Brenda S. A. and Katie Willis. 2005. "Singaporeans in China: Transnational Women Elites and the Negotiation of Gendered Identities." Geoforum 36 (2):211222. https://doi.org/10.1016/j.geoforum.2003.07.004.

Zlotnik, H. 1990. "International Migration Policies and the Status of Female Migrants." International Migration Review 24 (2):372-381. doi:10.2307/2546556.

Zlotnik, H. 1995. "The South-to-North Migration of Women." International Migration Review 29 (1):229-254. doi:10.2307/2547003.

Adserà, Alícia and Ana Ferrer. 2016. "Occupational Skills and Labour Market Progression of Married Immigrant Women in Canada.” Labour Economics 39:88-98. doi: https://doi.org/10.1016/j.labeco.2016.02.003.

Aure, Marit. 2013. "Highly Skilled Dependent Migrants Entering the Labour Market: Gender and Place in Skill Transfer." Geoforum 45:277-286. doi:10.1016/j. geoforum.2012.11.015.

Beach, C. M. and C. Worswick. 1993. "Is There a Double-Negative Effect on the Earnings of Immigrant Women." Canadian Public Policy-Analyse De Politiques 19 (1):36-53. doi: $10.2307 / 3551789$.

Beck-Gernsheim, Elisabeth. 2001. "Chapter 3: Housework-Migrant Women and Marriage-Migrant Women: Women in a Globalizing World." Counterpoints 242:61-80.

Beetz, Stephan and Tsypylma Darieva. 1997. "Ich heiratete nicht nur den Mann, sondern auch das Land.” Pp. 386-405 in Zuwanderung und Stadtentwicklung, edited by H. Häußermann and I. Oswald. Wiesbaden: Springer.

Bielby, William T. and Denise D. Bielby. 1992. "I Will Follow Him: Family Ties, Gender-Role Beliefs, and Reluctance to Relocate for a Better Job." American Journal of Sociology 97 (5):1241-1267. doi:10.1086/229901.

Block, Laura. 2016. Policy Frames on Spousal Migration in Germany: Regulating Membership, Regulating the Family. Wiesbaden: Springer VS.

Block, Laura and Saskia Bonjour. 2013. "Fortress Europe or Europe of Rights? The Europeanisation of Family Migration Policies in France, Germany and the Netherlands." European Journal of Migration and Law 15 (2):203-224. doi:10.1163/ 15718166-12342031.

Bonjour, Saskia and Betty de Hart. 2013. "A Proper Wife, a Proper Marriage: Constructions of 'Us' and 'Them' in Dutch Family Migration Policy." European Journal of Women's Studies 20 (1):61-76. doi:10.1177/1350506812456459. 
Bonjour, Saskia and Albert Kraler. 2015. "Introduction: Family Migration as an Integration Issue? Policy Perspectives and Academic Insights." Journal of Family Issues 36 (11):1407-1432. doi:10.1177/0192513X14557490.

Boyd, Monica. 1984. "At a Disadvantage: The Occupational Attainments of Foreign Born Women in Canada." The International Migration Review 18 (4):1091-1119. doi: $10.2307 / 2546074$.

Boyd, Monica. 1985. "Immigration and Occupational Attainment in Canada." Pp. 393-446 in Ascription and Achievement, Studies in Mobility and Status Attainment in Canada, edited by M. Boyd, J. Goyder, F. E. Jones, H. A. McRoberts, P. C. Pineo and J. Porter. Montreal and Kingston, Canada: McGill-Queen's University Press.

Boyd, Monica. 1997. "Migration Policy, Female Dependency and Family Membership: Canada and Germany." Pp. 142-169 in Women and the Canadian Welfare State: Challenge and Change, edited by P. M. Evans and G. R. Wekerle. Toronto; Buffalo; London: University of Toronto Press.

Boyle, Paul and Keith Halfacree, eds. 1999. Migration and Gender in the Developed World. London; New York: Routledge. (Publisher description http://www.loc.gov/ca tdir/enhancements/fy0649/98044333-d.html.)

Boyle, Paul, Thomas J. Cooke, Keith Halfacree and Darren Smith. 2001. "A CrossNational Comparison of the Impact of Family Migration on Women's Employment Status.” Demography 38 (2):201-213. doi:10.1353/dem.2001.0012.

Breger, Rosemary. 1998. "Love and the State: Women, Mixed Marriages and the Law in Germany." Pp. 129-152 in Cross-Cultural Marriage: Identity and Choice, edited by R. Breger and R. Hill. Oxford; New York: Berg.

Brekke, Idunn. 2013. "How Do Husbands Affect the Labour Market Participation of Majority and Immigrant Women?" Journal of Ethnic and Migration Studies 39 (10):1639-1657. doi:10.1080/1369183x.2013.833693.

Browne, I. and J. Misra. 2003. "The Intersection of Gender and Race in the Labor Market." Annual Review of Sociology 29:487-513. doi:10.1146/annurev.soc.29.010202.100016.

Bruegel, Irene. 1996. "The Trailing Wife. A Declining Breed?" Pp. 235-258 in Changing Forms of Employment: Organizations, Skills and Gender, edited by R. Crompton, D. Gallie and K. Purcell. London; New York: Routledge.

Büttner, Tobias and Anja Stichs. 2014. "Die Integration von Zugewanderten Ehegattinnen und Ehegatten in Deutschland.” Forschungsbericht 22. Nürnberg: Bundesamt für Migration und Flüchtlinge.

Coles, Anne and Anne-Meike Fechter, eds. 2008. Gender and Family among Transnational Professionals. New York: Routledge. (Table of contents only http://www.loc.gov/catdir/ toc/ecip0713/2007009503.html.)

Constable, Nicole, ed. 2005a. Cross-Border Marriages: Gender and Mobility in Transnational Asia. Philadelphia, PA: University of Pennsylvania Press.

Constable, Nicole. 2005b. "Introduction: Cross-Border Marriages, Gendered Mobility, and Global Hypergamy." Pp. 1-16 in Cross-Border Marriages: Gender and Mobility in Transnational Asia, edited by N. Constable. Philadelphia, PA: University of Pennsylvania Press.

Cooke, Fang Lee. 2007. “'Husband's Career First': Renegotiating Career and Family Commitment among Migrant Chinese Academic Couples in Britain." Work, Employment and Society 21 (1):47-65. doi:10.1177/0950017007073615.

Cottrell, Ann Baker. 1990. "Cross-National Marriages: A Review of the Literature." Journal of Comparative Family Studies 21 (2):151-169. doi:10.3138/jcfs.21.2.151. 
Eggebo, H. 2010. "The Problem of Dependency: Immigration, Gender, and the Welfare State.” Social Politics 17 (3):295-322. doi:10.1093/sp/jxq013.

Esser, Hartmut. 2001. "Integration und ethnische Schichtung." Arbeitspapiere 40. Mannheim: Mannheimer Zentrum für Europäische Sozialforschung.

Friese, Marianne. 1995. "East European Women as Domestics in Western Europe New Social Inequality and Division of Labour among Women." Journal of Area Studies 3 (6):194-202. doi:10.1080/02613539508455748.

García-Ramon, Maria Dolors and Janice J. Monk. 1996. "Placing Women of the European Union." Pp. 1-30 in Women of the European Union: The Politics of Work and Daily Life, edited by M. D. García-Ramon and J. J. Monk. London; New York: Routledge.

Greenman, E. and Y. Xie. 2008. "Double Jeopardy? The Interaction of Gender and Race on Earnings in the United States." Social Forces 86 (3):1217-1244.

Grote, Janne. 2017. "Family Reunification of Third-Country Nationals in Germany." Working Paper 73 of the Research Centre of the Federal Office for Migration and Refugees. Federal Office for Migration and Refugees, Nuremberg.

Halfacree, Keith and Paul Boyle. 1999. "Introduction: Gender and Migration in Developed Countries." Pp. 1-29 in Migration and Gender in the Developed World, edited by P. Boyle and K. Halfacree. London; New York: Routledge.

Hardill, Irene. 2002. Gender, Migration and the Dual Career Household. London; New York: Routledge.

Ho, C. 2006. "Migration as Feminisation? Chinese Women's Experiences of Work and Family in Australia." Journal of Ethnic and Migration Studies 32 (3):497-514. doi:10.1080/13691830600555053.

Humbeck, Eva. 1996. "The Politics of Cultural Identity: Thai Women in Germany." Pp. 186-201 in Women of the European Union: The Politics of Work and Daily Life, edited by M. D. García-Ramon and J. J. Monk. London; New York: Routledge.

Iredale, R. 2001. "The Migration of Professionals: Theories and Typologies." International Migration 39 (5):7-26. doi:10.1111/1468-2435.00169.

Iredale, R. 2005. "Gender Immigration Policies and Accreditation: Valuing the Skills of Professional Women Migrants." Geoforum 36 (2):155-166. doi:10.1016/j. geoforum.2004.04.002.

Jakobsen, Vibeke and Anika Liversage. 2017. "From Work to Welfare: Institutional Arrangements Shaping Turkish Marriage Migrants' Gendered Trajectories into a New Society.” International Migration Review 51 (4):964-998. doi:10.1111/imre.12264.

Khoudja, Y. and F. Fleischmann. 2017. "Labor Force Participation of Immigrant Women in the Netherlands: Do Traditional Partners Hold Them Back?" International Migration Review 51 (2):506-541. doi:10.1111/imre.12228.

Kofman, Eleonore. 1999. "Female 'Birds of Passage' a Decade Later: Gender and Immigration in the European Union.” International Migration Review 33 (2):269-299. doi: $10.2307 / 2547698$.

Kofman, Eleonore. 2000a. "Beyond a Reductionist Analysis of Female Migrants in Global European Cities: The Unskilled, Deskilled, and Professional.” Pp. 132-142 in Gender and Global Restructuring. Sightings, Sites and Resistances, edited by M. H. Marchand and A. S. Runyan. London: Routledge.

Kofman, Eleonore. 2000b. "The Invisibility of Skilled Female Migrants and Gender Relations in Studies of Skilled Migration in Europe." International Journal of Population Geography 6 (1):45-59. 
Kofman, Eleonore. 2004. "Family-Related Migration: A Critical Review of European Studies." Journal of Ethnic and Migration Studies 30 (2):243-262. doi:10.1080/ 1369183042000200687.

Kofman, Eleonore, Annie Phizacklea, Parvati Raghuram and Rosemary Sales. 2000. Gender and International Migration in Europe: Employment, Welfare, and Politics. London; New York: Routledge.

Kofman, Eleonore and Parvati Raghuram. 2005. "Gender and Skilled Migrants: Into and Beyond the Work Place." Geoforum 36 (2):149-154. doi: http://dx.doi.org/10. 1016/j.geoforum.2004.06.001.

Kofman, Eleonore, Albert Kraler, Martin Kohli and Camille Schmoll. 2011. "Introduction: Issues and Debates on Family-Related Migration and the Migrant Family: A European Perspective.” Pp. 13-54 in Gender, Generations and the Family in International Migration, edited by A. Kraler, E. Kofman, M. Kohli and C. Schmoll. Amsterdam: Amsterdam University Press.

Kofman, Eleonore, Sawitri Saharso and Elena Vacchelli. 2013. "Gendered Perspectives on Integration Discourses and Measures." International Migration 53 (4):77-89. doi:10.1111/imig.12102.

Le, A. T. and P. W. Miller. 2010. "Glass Ceiling and Double Disadvantage Effects: Women in the US Labour Market." Applied Economics 42 (5):603-613. doi:10.1080/ 00036840701704501.

Lee, Maggy, Anita Chan, Hannah Bradby and Gill Green. 2002. "Chinese Migrant Women and Families in Britain." Women's Studies International Forum 25 (6):607618. doi: https://doi.org/10.1016/S0277-5395(02)00339-00334.

Li, Lin and Allan Findlay. 1999. "To Follow the Chicken or Not? The Role of Women in the Migration of Hong Kong Professional Couples." Pp. 172-185 in Migration and Gender in the Developed World, edited by P. Boyle and K. Halfacree. London; New York: Routledge.

Liversage, Anika. 2009a. "Finding a Path: Investigating the Labour Market Trajectories of High-Skilled Immigrants in Denmark." Journal of Ethnic and Migration Studies 35 (2):203-226. doi:10.1080/13691830802586195.

Liversage, Anika. 2009b. "Vital Conjunctures, Shifting Horizons: High-Skilled Female Immigrants Looking for Work." Work Employment and Society 23 (1):120-141. doi:10.1177/0950017008099781.

Man, Guida. 2004. "Gender, Work and Migration: Deskilling Chinese Immigrant Women in Canada." Women's Studies International Forum 27 (2):135-148. doi: http://dx.doi.org/10.1016/j.wsif.2004.06.004.

Mandel, Hadas and Michael Shalev. 2009. "How Welfare States Shape the Gender Pay Gap: A Theoretical and Comparative Analysis.” Social Forces 87 (4):18731911. doi:10.1353/sof.0.0187.

Mix, Prapairat R. and Nicola Piper. 2003. "Does Marriage 'Liberate' Women from Sex Work?-Thai Women in Germany." Pp. 53-72 in Wife or Worker?: Asian Women and Migration, edited by N. Piper and M. Roces. Lanham, MD: Rowman \& Littlefield Publishers.

OECD. 2017. International Migration Outlook 2017. Paris: OECD Publishing.

Pellander, Saara. 2014. "An Acceptable Marriage': Marriage Migration and Moral Gatekeeping in Finland." Journal of Family Issues 36 (11):1472-1489. doi:10.1177/ $0192513 X 14557492$. 
Piper, Nicola and Mina Roces. 2003. "Introduction: Marriage and Migration in an Age of Globalization.” Pp. 1-21 in Wife or Worker?: Asian Women and Migration, edited by N. Piper and M. Roces. Lanham, MD: Rowman \& Littlefield Publishers.

Purkayastha, Bandana. 2005. "Skilled Migration and Cumulative Disadvantage: The Case of Highly Qualified Asian Indian Immigrant Women in the US." Geoforum 36 (2):181-196. doi: http://dx.doi.org/10.1016/j.geoforum.2003.11.006.

Raghuram, Parvati. 2004. "The Difference That Skills Make: Gender, Family Migration Strategies and Regulated Labour Markets." Journal of Ethnic \& Migration Studies 30 (2):303-321. doi:10.1080/1369183042000200713.

Read, J. G. 2004. "Cultural Influences on Immigrant Women's Labor Force Participation: The Arab-American Case." International Migration Review 38 (1):52-77.

Refsing, Kirsten. 1998. "Gender Identity and Gender Role Patterns in Cross-Cultural Marriages: The Japanese-Danish Case.” Pp. 193-208 in Cross-Cultural Marriage: Identity and Choice, edited by R. Breger and R. Hill. Oxford; New York: Berg.

Remennick, L. 2009. "Exploring Intercultural Relationships: A Study of Russian Immigrants Married to Native Israelis." Journal of Comparative Family Studies 40 (5):719-738.

Riaño, Yvonne. 2011. “'He's the Swiss Citizen, I'm the Foreign Spouse': Binational Marriages and the Impact of Family-Related Migration Policies on Gender Relations." Pp. 265-284 in Gender, Generations and the Family in International Migration, edited by A. Kraler, E. Kofman, M. Kohli and C. Schmoll. Amsterdam: Amsterdam University Press.

Riaño, Yvonne. 2014. "Highly Skilled Migrant Women: Dual-Career Households, Family Considerations and Gender Roles.” Pp. 77-85 in Harnessing Knowledge on the Migration of Highly Skilled Women, edited by B. Mollard and J. Gagnon. Geneva, Switzerland: International Organization for Migration (IOM).

Riaño, Yvonne. 2015. "Latin American Women Who Migrate for Love: Imagining European Men as Ideal Partners." Pp. 45-60 in Rethinking Romantic Love: Discussions, Imaginaries and Practices, edited by B. Enguix and J. Roca. Newcastle upon Tyne, UK: Cambridge Scholars Publishing.

Roer-Strier, Dorit and Dina Ben Ezra. 2006. "Intermarriages between Western Women and Palestinian Men: Multidirectional Adaptation Processes." Journal of Marriage and Family 68 (1):41-55. doi:10.1111/j.1741-3737.2006.00232.x.

Scott, Sam and Kim H. Cartledge. 2009. "Migrant Assimilation in Europe: A Transnational Family Affair." The International Migration Review 43 (1):60-89.

Seyhan, Azade. 1997. "Scheherzade's Daughters: The Thousand and One Tales of Turkish-German Women Writers." Pp. 230-248 in Writing New Identities: Gender, Nation, and Immigration in Contemporary Europe, edited by G. Brinkler-Gabler and S. Smith. Minneapolis; London: University of Minnesota Press.

Shinozaki, Kyoko. 2014. "Career Strategies and Spatial Mobility among Skilled Migrants in Germany: The Role of Gender in the Work-Family Interaction." Tijdschrift voor economische en sociale geografie 105 (5):526-541. doi:10.1111/tesg.12111.

Strasser, Elisabeth, Albert Kraler, Saskia Bonjour and Veronika Bilger. 2009. "Doing Family: Responses to the Constructions of 'the Migrant Family' across Europe." The History of the Family 14 (2):165-176. doi:10.1016/j.hisfam.2009.02.005.

van der Lippe, T. and L. van Dijk. 2002. "Comparative Research on Women's Employment." Annual Review of Sociology 28:221-241. doi:10.1146/annurev. soc.28.110601.140833.

van Tubergen, Frank. 2008. "The Impact of the Partner on the Economic Incorporation of Immigrants: Household Specialization or Social Capital?” Pp. 488-512 in 
Migration Und Integration, Vol. 48, Kölner Zeitschrift Für Soziologie Und Sozialpsychologie. Sonderheft, edited by F. Kalter. Wiesbaden: VS Verlag für Sozialwissenschaften.

Wei, Wenchao. 2013. "My Home Is Where My Husband Is: Chinese Wives' Attitudes Towards Family Migration to the United Kingdom." Families, Relationships and Societies 2 (1):115-127. doi:10.1332/204674313X664734.

Wray, H. 2006. "An Ideal Husband? Marriages of Convenience, Moral Gate-Keeping and Immigration to the UK." European Journal of Migration and Law 8 (3-4):303-320. doi:10.1163/157181606778882582.

Yeoh, Brenda S. A. and Katie Willis. 2005. "Singaporeans in China: Transnational Women Elites and the Negotiation of Gendered Identities." Geoforum 36 (2):211-222. doi: https://doi.org/10.1016/j.geoforum.2003.07.004.

Allmendinger, Jutta. 1989. "Educational Systems and Labor Market Outcomes." European Sociological Review 5 (3):231-250.

Alwin, Duane F., Michael Braun and Jacqueline Scott. 1992. "The Separation of Work and the Family: Attitudes Towards Women's Labour-Force Participation in Germany, Great Britain, and the United States." European Sociological Review 8 (1):13-37.

Anerkennung in Deutschland. 2017. "Anerkennungsgesetz des Bundes". Retrieved April 12, 2018 (https://www.anerkennung-in-deutschland.de/html/de/anerkennungs gesetz_des_bundes.php).

Attané, Isabelle. 2012. "Being a Woman in China Today: A Demography of Gender" China Perspectives 4:5-15. Retrieved May 4, 2018 (http://journals.openedition.org/ chinaperspectives/6013).

Bayerische Staatszeitung, BSZ. 2018. "Familiengeld ersetzt Betreuungsgeld." PolitikBayerische Staatszeitung, BSZ. Retrieved April 19, 2018 (http://www.bayer ische-staatszeitung.de/staatszeitung/politik/detailansicht-politik/artikel/familiengel d-ersetzt-betreuungsgeld.html).

Bayerisches Staatsministerium für Familie, Arbeit und Soziales, StMAS Bayern. 2017. "Familienministerin Müller: „Schon über 150.000 Anträge bewilligt - Familien schätzen und nutzen das Bayerische Betreuungsgeld!“ - Ein Jahr Bayerisches Betreuungsgeld." Pressemitteilung: Bayerisches Staatsministerium für Familie, Arbeit und Soziales, StMAS Bayern. Retrieved April 19, 2018 (https://www.stmas. bayern.de/aktuelle-meldungen/pm1706-258.php).

BBC Radio World Service. 2017. "Economist Sir Paul Collier." In HARDTalk, edited by S. Montague.

Beck-Gernsheim, Elisabeth. 1980. Das halbierte Leben: Männerwelt Beruf, Frauenwelt Familie. Frankfurt am Main: Fischer-Taschenbuch-Verlag.

Beck-Gernsheim, Elisabeth. 2001. "Chapter 3: Housework-Migrant Women and Marriage-Migrant Women: Women in a Globalizing World.” Counterpoints 242:61-80.

Beck-Gernsheim, Elisabeth and Ilona Ostner. 1978. "Frauen verändern - Berufe nicht? Ein theoretischer Ansatz zur Problematik von „Frau und Beruf“.” Soziale Welt 29 (3):257-287.

Beetz, Stephan and Tsypylma Darieva. 1997. "Ich heiratete nicht nur den Mann, sondern auch das Land.” Pp. 386-405 in Zuwanderung und Stadtentwicklung, edited by H. Häußermann and I. Oswald. Wiesbaden: Springer.

Bittman, Michael, Paula England, Liana Sayer, Nancy Folbre and George Matheson. 2003. "When Does Gender Trump Money? Bargaining and Time in Household Work.” American Journal of Sociology 109 (1):186-214. doi:10.1086/378341. 
Block, Laura. 2016. Policy Frames on Spousal Migration in Germany: Regulating Membership, Regulating the Family. Wiesbaden: Springer VS.

Blossfeld, Hans-Peter. 1987. "Labor-Market Entry and the Sexual Segregation of Careers in the Federal Republic of Germany." American Journal of Sociology 93 (1):89-118. doi:10.1086/228707.

Bouffier, Anna. 2017. "Careers against the Odds - Barrieren und Chancen für Wissenschaftsmigrantinnen in Naturwissenschaft und Technik." Pp. 145-172 in Hochqualifizierte Migrantinnen: Teilhabe an Arbeit und Gesellschaft, edited by I. Jungwirth and A. Wolffram. Opladen; Berlin; Toronto: Verlag Barbara Budrich.

Bouvard, Flore, Laurence Rambert, Lucile Romanello and Nicolas Studer. 2013. "How Have the Hartz Reforms Shaped the German Labor Market?” Trésor-Economics No. 110. Ministère de l'Économie et des Finances et Ministère du Commerce Extérieur.

Boyd, Monica. 1997. "Migration Policy, Female Dependency and Family Membership: Canada and Germany." Pp. 142-169 in Women and the Canadian Welfare State: Challenge and Change, edited by P. M. Evans and G. R. Wekerle. Toronto; Buffalo; London: University of Toronto Press.

Braun, Michael, Jacqueline Scott and Duane F. Alwin. 1994. "Economic Necessity or Self-Actualization? Attitudes toward Women's Labour-Force Participation in East and West Germany." European Sociological Review 10 (1):29-47.

Brines, Julie. 1994. "Economic Dependency, Gender, and the Division of Labor at Home." American Journal of Sociology 100 (3):652-688.

Brinton, Mary C. 2001. "Married Women's Labor in East Asian Economies.” Pp. 1-37 in Women's Working Lives in East Asia, edited by M. C. Brinton. Stanford, CA: Stanford University Press.

Brinton, Mary C., Yean-Ju Lee and William L. Parish. 1995. "Married Women's Employment in Rapidly Industrializing Societies: Examples from East Asia." American Journal of Sociology 100 (5):1099-1130.

Bundesamt für Migration und Flüchtlinge, BAMF. 2016a. "Migrationsbericht 2015." Nürnberg: Bundesamt für Migration und Flüchtlinge. Retrieved April 6, 2018 (http://www.bamf.de/SharedDocs/Anlagen/DE/Publikationen/Migrationsberichte/m igrationsbericht-2015.html?nn=1663558).

Bundesamt für Migration und Flüchtlinge, BAMF. 2016b. "Ehegattennachzug." Retrieved December 27, 2016 (http://www.bamf.de/DE/Migration/EhepartnerFam ilie/ehepartnerfamilie-node.html).

Bundesgesetzblatt Online, BGBI. 1990. "Gesetz über die Einreise und den Aufenthalt von Ausländern im Bundesgebiet (Ausländergesetz) 1354, 1356.” Retrieved April 10, 2018 (http://www.bgbl.de/xaver/bgbl/start.xav?startbk=Bundesanzeiger_BGB1\& jumpTo=bgbl190s1354.pdf).

Bundesministerium der Justiz und für Verbraucherschutz, BMJV. 2016a. "Gesetz über den Aufenthalt, der Erwerbstätigkeit und die Integration von Ausländern im Bundesgebiet." Retrieved December 26, 2016 (http://www.gesetze-im-internet.de/a ufenthg_2004/index.html\#BJNR195010004BJNE016415116).

Bundesministerium der Justiz und für Verbraucherschutz, BMJV. 2016b. "Aufenthaltsverordung (AufenthV): $\$ 41$ Vergüngstigung für Angehörige bestimmter Staaten." Retrieved December 31, 2016 (https://www.gesetze-im-internet.de/aufenthv/_41.html).

Bundesministerium der Justiz und für Verbraucherschutz, BMJV. 2018. "Verordnung über die Durchführung von Integrationskursen für Ausländer und Spätaussiedler." Retrieved June 17, 2018 (https://www.gesetze-im-internet.de/intv/index.html). 
Bundesministerium für Arbeit und Soziales, BMAS. 2014. "450 Euro Mini Jobs/Marginal Employment": Bundesministerium für Arbeit und Soziales, BMAS. Retrieved April 17, 2018 (http://www.bmas.de/EN/Our-Topics/Social-Security/450-euro-mini-jobs-ma rginal-employment.html).

Bussemaker, Jet and Kees van Kersbergen. 1994. "Gender and Welfare States: Some Theoretical Reflections.” Pp. 8-25 in Gendering Welfare States, edited by D. Sainsbury. London; Thousand Oaks, Calif:: SAGE Publications Ltd.

Büttner, Tobias and Anja Stichs. 2014. "Die Integration von zugewanderten Ehegattinnen und Ehegatten in Deutschland.” Forschungsbericht 22. Nürnberg: Bundesamt für Migration und Flüchtlinge.

Carpenter, Doreen. 2018. "Das neue Integrationsgesetz." Pp. 31-39 in Berufliche Integration von Flüchtlingen und Migranten: Psychologische Kompetenzanalyse, rechtliche Rahmenbedingungen, Prozessgestaltung \& Praxisbeispiele, edited by A. Frintrup. Berlin, Heidelberg: Springer Berlin Heidelberg.

Chang, Chin-fen. 2006. "The Employment Discontinuity of Married Women in Taiwan: Job Status, Ethnic Background and Motherhood." Current Sociology 54 (2):209-228. doi:10.1177/0011392106056743.

Cheung, Fanny M. and Catherine S. K. Tang. 2017. "Women's Lives in Contemporary Chinese Societies." Pp. 19-38 in Women's Evolving Lives: Global and Psychosocial Perspectives, edited by C. M. B. Brown, U. P. Gielen, J. L. Gibbons and J. Kuriansky. New York, NY: Springer International Publishing.

Cooke, Fang Lee. 2010. "Women's Participation in Employment in Asia: A Comparative Analysis of China, India, Japan and South Korea." International Journal of Human Resource Management 21 (12):2249-2270. doi:10.1080/09585192.2010.509627.

Daly, Mary. 1994. "Comparing Welfare States: Towards a Gender Friendly Approach.” Pp. 101-117 in Gendering Welfare States, edited by D. Sainsbury. London; Thousand Oaks, Calif:: SAGE Publications Ltd.

Daly, Mary. 2000. The Gender Division of Welfare: The Impact of the British and German Welfare States. Cambridge, UK; New York: Cambridge University Press.

Diamond, Norma. 1973. "The Middle Class Family Model in Taiwan: Woman's Place Is in the Home." Asian Survey 13 (9):853-872.

Dingeldey, Irene. 2001. "European Tax Systems and Their Impact on Family Employment Patterns." Journal of Social Policy 30 (04):653-672.

DiPrete, T. A., C. C. Eller, T. Bol and H. G. van de Werfhorst. 2017. "School-to-Work Linkages in the United States, Germany, and France." American Journal of Sociology 122 (6):1869-1938. doi:10.1086/691327.

Eggebo, H. 2010. "The Problem of Dependency: Immigration, Gender, and the Welfare State.” Social Politics 17 (3):295-322. doi:10.1093/sp/jxq013.

Eichhort, Werner and Michael J. Kendzia. 2014. "Workforce Segmentation in Germany: From the Founding Era to the Present Time." Discussion Paper No. 8648. Forschungsinstitut zur Zukunft der Arbeit, IZA, Bonn.

Englmann, Bettina and Martina Müller. 2007. Brain Waste. Die Anerkennung von ausländischen Qualifikationen in Deutschland. Augsburg: Tür an Tür Integrationsprojekte - gGmbH.

Esping-Andersen, Gøsta. 1990. The Three Worlds of Welfare Capitalism. Cambridge, UK: Polity Press.

EUR-Lex. 2003. "Council Directive 2003/86/EC of 22 September 2003 on the Right to Family Reunification.” Retrieved April 10, 2018 (http://data.europa.eu/eli/dir/2003/86/oj). 
EUR-Lex. 2011. "Regulation (EU) No 492/2011 of the European Parliament and of the Council of 5 April 2011 on Freedom of Movement for Workers within the Union Text with EEA Relevance.” Retrieved April 9, 2018 (http://eur-lex.europa.eu/ eli/reg/2011/492/oj).

European Court of Justice. 2014. Judgment of 10 July 2014, Naime Dogan v Bundesrepublik Deutschland, C-138/13, Ecli:EU:C:2014:2066 (2014).

Evans, Harriet. 2008. The Subject of Gender: Daughters and Mothers in Urban China. Lanham, MD; Plymouth, UK: Rowman \& Littlefield Publishers, inc.

Fahlén, Susanne. 2016. "Equality at Home - A Question of Career? Housework, Norms, and Policies in a European Comparative Perspective." Demographic Research 35 (48):1411-1440.

Gangl, M. and A. Ziefle. 2009. "Motherhood, Labor Force Behavior, and Women's Careers: An Empirical Assessment of the Wage Penalty for Motherhood in Britain, Germany, and the United States." Demography 46 (2):341-369.

Gangl, Markus and Andrea Ziefle. 2015. "The Making of a Good Woman: Extended Parental Leave Entitlements and Mothers' Work Commitment in Germany." American Journal of Sociology 121 (2):511-563. doi:10.1086/682419.

Greenstein, Theodore N. 2000. "Economic Dependence, Gender, and the Division of Labor in the Home: A Replication and Extension." Journal of Marriage and Family $62(2): 322-335$.

Grote, Janne. 2017. "Family Reunification of Third-Country Nationals in Germany." Working Paper 73 of the Research Centre of the Federal Office for Migration and Refugees. Federal Office for Migration and Refugees, Nuremberg.

Gustafsson, Siv. 1992. "Separate Taxation and Married Women's Labor Supply: A Comparison of West Germany and Sweden." Journal of Population Economics 5 (1):61-85.

Gustafsson, Siv. 1994. "Childcare and Types of Welfare States." Pp. 45-61 in Gendering Welfare States, edited by D. Sainsbury. London; Thousand Oaks, Calif.: SAGE Publications Ltd.

Hanel, Barbara and Regina T. Riphahn. 2012. "The Employment of Mothers - Recent Developments and Their Determinants in East and West Germany." Jahrbücher für Nationalökonomie und Statistik 232 (2):146-176.

Harhoff, Dietmar and Thomas J. Kane. 1997. "Is the German Apprenticeship System a Panacea for the U.S. Labor Market?" Journal of Population Economics 10 (2):171-196. doi:10.1007/s001480050037.

Heizmann, B., A. Busch-Heizmann and E. Holst. 2017. "Immigrant Occupational Composition and the Earnings of Immigrants and Natives in Germany: Sorting or Devaluation?" International Migration Review 51 (2):475-505. doi:10.1111/imre.12209.

Heß, Barbara. 2009. "Zuwanderung von Hochqualifizierten aus Drittstaaten nach Deutschland. Ergebnisse einer schriftlichen Befragung." Working Paper der Forschungsgruppe des Bundesamtes, 28. Bundesamt für Migration und Flüchtlinge, Nürnberg.

Heß, Barbara. 2012. "Zuwanderung von Frachkräften nach $\S 18$ AufenthG aus Drittstaaten nach Deutschland. Ergebnisse einer schriftlichen Befragung von Arbeitsmigranten." Working Paper 44 der Forschungsgruppe des Bundesamtes. Bundesamt für Migration und Flüchtlinge, Nürnberg

Hsieh, Kuang-Hua and Robert L. Burgess. 1994. "Marital Role Attitudes and Expected Role Behaviors of College Youth in Mainland China and Taiwan." Journal of Family Issues 15 (3):403-423. doi:10.1177/019251394015003004. 
Jungwirth, Ingrid. 2012a. "Geographische Mobilität und beschränkte Möglichkeiten Berufsverläufe hochqualifizierter Migrantinnen.” Pp. 15-24 in Arbeitsmarktintegration hochqualifizierter Migrantinnen. Berufsverläufe in Naturwissenschaft und Tech$n i k$, edited by I. Jungwirth, G. Grigoleit, A. Wolffram and A. Bouffier. Bonn; Berlin: Bundesministerium für Bildung und Forschung, BMBF.

Jungwirth, Ingrid. 2012b. "Eine Frage des Geschlechts - Arbeitsmarktintegration hochqualifizierter Migrantinnen und Migranten.” Pp. 8-13 in Arbeitsmarktintegration hochqualifizierter Migrantinnen. Berufsverläufe in Naturwissenschaft und Tech$n i k$, edited by I. Jungwirth, G. Grigoleit, A. Wolffram and A. Bouffier. Bonn; Berlin: Bundesministerium für Bildung und Forschung, BMBF.

Jungwirth, Ingrid. 2017. "Geschlecht und Migration in der Lebenslaufanalyse - Berufsverläufe hochqualifizierter Migrantinnen im technischen Feld und darüber hinaus." Pp. 33-82 in Hochqualifizierte Migrantinnen: Teilhabe an Arbeit und Gesellschaft, edited by I. Jungwirth and A. Wolffram. Opladen; Berlin; Toronto: Verlag Barbara Budrich.

Jungwirth, Ingrid, Grit Grigoleit, Andrea Wolffram and Anna Bouffier. 2012. "Arbeitsmarktintegration hochqualifizierter Migrantinnen. Berufsverläufe in Naturwissenschaft und Technik." Bonn; Berlin: Bundesministerium für Bildung und Forschung, BMBF. Retrieved April 7, 2018 (http://www.esf.de/portal/SharedDocs/PDFs/DE/Programm e-2007-2013/Beschaeftigung-Soziale-Integration/2012_bmbf_arbeitsmarktintegration_m igrantinnen.pdf?_blob=publicationFile $\& v=3$ ).

Jungwirth, Ingrid and Andrea Wolffram, eds. 2017. Hochqualifizierte Migrantinnen: Teilhabe an Arbeit und Gesellschaft. Opladen; Berlin; Toronto: Verlag Barbara Budrich.

Kandiyoti, Deniz. 1988. "Bargaining with Patriarchy.” Gender and Society 2 (3):274-290.

Kofman, Eleonore. 1999. "Female 'Birds of Passage' a Decade Later: Gender and Immigration in the European Union.” International Migration Review 33 (2):269-299. doi: $10.2307 / 2547698$.

Kofman, Eleonore. 2004. "Family-Related Migration: A Critical Review of European Studies." Journal of Ethnic and Migration Studies 30 (2):243-262. doi:10.1080/ 1369183042000200687.

Kofman, Eleonore, Annie Phizacklea, Parvati Raghuram and Rosemary Sales. 2000. Gender and International Migration in Europe: Employment, Welfare, and Politics. London; New York: Routledge.

Koopmans, R. 2016. "Does Assimilation Work? Sociocultural Determinants of Labour Market Participation of European Muslims." Journal of Ethnic and Migration Studies 42 (2):197-216. doi:10.1080/1369183x.2015.1082903.

Leitner, Sigrid. 2013. Varianten von Familialismus: eine historisch vergleichende Analyse der Kinderbetreuungs- und Altenpflegepolitiken in kontinentaleuropäischen Wohlfahrtsstaaten. Berlin: Duncker \& Humblot.

Leitner, Sigrid, Ilona Ostner and Margit Schratzenstaller, eds. 2004. Wohlfahrtsstaat und Geschlechterverhältnis im Umbruch: was Kommt nach dem Ernährermodell? Wiesbaden: VS Verlag für Sozialwissenschaften.

Leitner, Sigrid, Ilona Ostner and Christoph Schmitt. 2008. "Family Policies in Germany." Pp. 175-202 in Family Policies in the Context of Family Change: The Nordic Countries in Comparative Perspective, edited by I. Ostner and C. Schmitt. Wiesbaden: VS Verlag für Sozialwissenschaften.

Lewis, Jane. 1992. "Gender and the Development of Welfare Regimes." Journal of European Social Policy 2 (3):159-173. doi:10.1177/095892879200200301. 
Lewis, Jane. 2002. “Gender and Welfare State Change.” European Societies 4 (4):331-357. doi:10.1080/1461669022000022324.

Lewis, J., T. Knijn, C. Martin and I. Ostner. 2008. "Patterns of Development in Work/ Family Reconciliation Policies for Parents in France, Germany, the Netherlands, and the UK in the 2000s." Social Politics 15 (3):261-286. doi:10.1093/sp/jxn016.

Lutz, Helma. 1991. "The Myth of the 'Other': Western Representation and Images of Migrant Women of So Called 'Islamic Background'." International Review of Sociology 2 (2):121-137. doi:10.1080/03906701.1991.9971091.

Mandel, Hadas and Moshe Semyonov. 2005. "Family Policies, Wage Structures, and Gender Gaps: Sources of Earnings Inequality in 20 Countries." American Sociological Review 70 (6):949-967. doi:10.1177/000312240507000604.

Mandel, Hadas and Moshe Semyonov. 2006. "A Welfare State Paradox: State Interventions and Women's Employment Opportunities in 22 Countries." American Journal of Sociology 111 (6):1910-1949. doi:10.1086/499912.

Mandel, Hadas and Michael Shalev. 2009. "How Welfare States Shape the Gender Pay Gap: A Theoretical and Comparative Analysis." Social Forces 87 (4):1873-1911. doi:10.1353/sof.0.0187.

Meyer, Traute. 1994. "The German and British Welfare States as Employers: Patriarchal or Emancipatory?" Pp. 62-81 in Gendering Welfare States, edited by D. Sainsbury. London; Thousand Oaks, Calif.: SAGE Publications Ltd.

Müller, Kai-Uwe, C. Katharina Spieß and Katharina Wrohlich. 2013. "Rechtsanspruch auf Kitaplatz ab zweitem Lebensjahr: Erwerbsbeteiligung von Müttern wird steigen und Kinder können in ihrer Entwicklung profitieren." DIW Wochenbericht 80 (32):3-12. (http://hdl.handle.net/10419/78871.)

O'Connor, Julia S. 1993. "Gender, Class and Citizenship in the Comparative Analysis of Welfare State Regimes: Theoretical and Methodological Issues." The British Journal of Sociology 44 (3):501-518. doi:10.2307/591814.

OECD. 2017. International Migration Outlook 2017. Paris: OECD Publishing.

Orloff, Ann Shola. 1993. "Gender and the Social Rights of Citizenship: The Comparative Analysis of Gender Relations and Welfare States." American Sociological Review 58 (3):303-328. doi:10.2307/2095903.

Ostner, Ilona. 2004. "Aus Anlass eines Geburtstags: 'Gender and Welfare Revisited'." Pp. 44-61 in Wohlfahrtsstaat und Geschlechterverhältnis im Umbruch: was Kommt nach dem Ernährermodell?, edited by S. Leitner, I. Ostner and M. Schratzenstaller. Wiesbaden: VS Verlag für Sozialwissenschaften.

Pfau-Effinger, Birgit. 1998. "Gender Cultures and the Gender Arrangement-A Theoretical Framework for Cross-National Gender Research." Innovation: The European Journal of Social Science Research 11 (2):147-166. doi:10.1080/ 13511610.1998.9968559.

Qian, Yue and Liana C. Sayer. 2016. "Division of Labor, Gender Ideology, and Marital Satisfaction in East Asia." Journal of Marriage and Family 78 (2):383-400. doi:10.1111/jomf.12274.

Raghuram, Parvati. 2004. "The Difference That Skills Make: Gender, Family Migration Strategies and Regulated Labour Markets." Journal of Ethnic \& Migration Studies 30 (2):303-321. doi:10.1080/1369183042000200713.

Raymo, James M., Hyunjoon Park, Yu Xie and Wei-jun Jean Yeung. 2015. "Marriage and Family in East Asia: Continuity and Change." Annual Review of Sociology 41 (1):471-492. doi:10.1146/annurev-soc-073014-112428. 
Riaño, Yvonne. 2011. “'He's the Swiss Citizen, I'm the Foreign Spouse': Binational Marriages and the Impact of Family-Related Migration Policies on Gender Relations." Pp. 265-284 in Gender, Generations and the Family in International Migration, edited by A. Kraler, E. Kofman, M. Kohli and C. Schmoll. Amsterdam: Amsterdam University Press.

Riaño, Yvonne. 2015. "Latin American Women Who Migrate for Love: Imagining European Men as Ideal Partners." Pp. 45-60 in Rethinking Romantic Love: Discussions, Imaginaries and Practices, edited by B. Enguix and J. Roca. Newcastle upon Tyne, UK: Cambridge Scholars Publishing.

Rosenfeld, Rachel A., Heike Trappe and Janet C. Gornick. 2004. "Gender and Work in Germany: Before and After Reunification." Annual Review of Sociology 30 (1):103-124. doi:10.1146/annurev.soc.30.012703.110531.

Sainsbury, Diane. 1994. Gendering Welfare States. London; Thousand Oaks, Calif.: SAGE Publications Ltd.

Schneider, Hilmar and Ulf Rinne. 2017. "The Labor Market in Germany, 2000-2016." IZA World of Labor 379. Retrieved April 11, 2018 (https://wol.iza.org/uploads/arti cles/379/pdfs/the-labor-market-in-germany.pdf?v=1).

Schweiwe, Kirsten. 1994. "German Pension Insurance, Gendered Times, and Stratification." Pp. 132-149 in Gendering Welfare States, edited by D. Sainsbury. London; Thousand Oaks, Calif.: Sage Publications.

Sechiyama, Kaku. 2013. Patriarchy in East Asia: A Comparative Sociology of Gender. Leiden: Brill.

Shinozaki, Kyoko. 2014. "Career Strategies and Spatial Mobility among Skilled Migrants in Germany: The Role of Gender in the Work-Family Interaction." Tijdschrift voor economische en sociale geografie 105 (5):526-541. doi:10.1111/tesg.12111.

Slote, Walter H. and George A. De Vos. 1998. Confucianism and the Family. Albany, NY: State University of New York Press.

Spieß, C. Katharina. 2011. "Betreuungsgeld: Anreize nicht außer Acht lassen." Wirtschaftsdienst 91 (12):809-810.

Spieß, C. Katharina. 2012. "Betreuungsgeld widerspricht den Zielen nachhaltiger Familienpolitik.” DIW Wochenbericht 79 (24):24. (http://hdl.handle.net/10419/61183.)

Tu, Su-Hao and Pei-Shan Liao. 2005. "Gender Differences in Gender-Role Attitudes: A Comparative Analysis of Taiwan and Coastal China." Journal of Comparative Family Studies 36 (4):545-566.

von Oertzen, C. and A. Rietzschel. 1997. "Comparing the Post-War Germanies: Breadwinner Ideology and Women's Employment in the Divided Nation, 19481970.” International Review of Social History 42:175-196.

Wei, Guoying. 2011. "Gender Comparison of Employment and Career Development in China." Asian Women 27 (1):95-113.

Weinkopf, Claudia. 2009. "Precarious Employment and the Rise of Minijobs." Pp. 177-193 in Gender and the Contours of Precarious Employment, edited by L. F. Vosko, M. MacDonald and I. Campbell. London: Routledge.

Weinkopf, Claudia. 2014. "Women's Employment in Germany. Robust in Crisis but Vulnerable in Job Quality." Revue de l'OFCE 133 (2):189-214. doi:10.3917/ reof.133.0189.

Willis, K. D. and B. S. A. Yeoh. 2000. "Gender and Transnational Household Strategies: Singaporean Migration to China.” Regional Studies 34 (3):253-264. doi:10.1080/ 00343400050015096. 
Wolffram, Andrea. 2017. "Wissenschaftlerinnen zwischen Mobilität und Migration." Pp. 119-144 in Hochqualifizierte Migrantinnen: Teilhabe an Arbeit und Gesellschaft, edited by I. Jungwirth and A. Wolffram. Opladen; Berlin; Toronto: Verlag Barbara Budrich.

Wolffram, Andrea and Anna Bouffier. 2012. "Wissenschaft in Deutschland - international und chancengleich? Karrierewege hochqualifizierter Migrantinnen an Hochschulen." Pp. $34-41$ in Arbeitsmarktintegration hochqualifizierter Migrantinnen. Berufsverläufe in Naturwissenschaft und Technik, edited by I. Jungwirth, G. Grigoleit, A. Wolffram and A. Bouffier. Bonn; Berlin: Bundesministerium für Bildung und Forschung, BMBF.

$\mathrm{Xu}$, Xiaohe and Shu-Chuan Lai. 2004. "Gender Ideologies, Marital Roles, and Marital Quality in Taiwan.” Journal of Family Issues 25 (3):318-355. doi:10.1177/ $0192513 \times 03257709$.

Yeoh, Brenda S. A. and Katie Willis. 2005. "Singaporeans in China: Transnational Women Elites and the Negotiation of Gendered Identities." Geoforum 36 (2):211-222. doi: https://doi.org/10.1016/j.geoforum.2003.07.004.

Yi, Chin-Chun, Yu-Hsia Lu and Yun-Kang Pan. 2000. "Women's Family Status: A Comparison of the Family Power Structure in Taiwan and China." Pp. 91-116 in Walking a Tightrope: Meeting the Challenges of Work and Family, edited by C. D. H. Harvey. Aldershot: Ashgate Publishing Limited.

Yi, Chin-Chun and Wen-Yin Chien. 2001. "The Continual Employment Patterns of Married Women in Taiwan: A Compromise between Family and Work." Taiwanese Sociology (1):149-182.

Yi, Chin-Chun and Wen-Yin Chien. 2002. "The Linkage between Work and Family: Female's Employment Patterns in Three Chinese Societies." Journal of Comparative Family Studies 33 (3):451-474.

Yu, Wei-hsin. 2005. "Changes in Women's Postmarital Employment in Japan and Taiwan.” Demography 42 (4):693-717. doi:10.1353/dem.2005.0039.

$\mathrm{Yu}$, Wei-hsin. 2006. "National Contexts and Dynamics of Married Women's Employment Reentry: The Cases of Japan and Taiwan." The Sociological Quarterly 47 (2):215-243. doi:10.1111/j.1533-8525.2006.00044.x.

Yu, Wei-hsin. 2009. Gendered Trajectories: Women, Work, and Social Change in Japan and Taiwan. Stanford, Calif.: Stanford University Press.

Zheng, Wang. 2003. "Gender, Employment and Women's Resistance.” Pp. 162-186 in Chinese Society: Change, Conflict and Resistance, edited by E. J. Perry and M. Selden. London: RoutledgeCurzon.

Zuo, Jiping and Yanjie Bian. 2001. "Gendered Resources, Division of Housework, and Perceived Fairness - a Case in Urban China." Journal of Marriage and Family 63 (4):1122-1133. doi:10.1111/j.1741-3737.2001.01122.x.

Alba, Richard and Victor Nee. 1997. "Rethinking Assimilation Theory for a New Era of Immigration.” The International Migration Review 31 (4):826-874. doi:10.2307/2547416.

Alba, Richard D. and Victor Nee. 2003. Remaking the American Mainstream: Assimilation and Contemporary Immigration. Cambridge, Mass.: Harvard University Press.

Berger, Peter L. and Thomas Luckmann. 1967. The Social Construction of Reality: A Treatise in the Sociology of Knowledge. London: Penguin P.

Bernard, William S. 1967. "The Integration of Immigrants in the United States." The International Migration Review 1 (2):23-33. doi:10.2307/3002806.

Bielby, DeniseDel Vento and William T. Bielby. 1984. "Work Commitment, Sex-Role Attitudes, and Women's Employment.” American Sociological Review 49 (2):234-247. doi:10.2307/2095573. 
Blumer, Herbert. 1969. Symbolic Interactionism: Perspective and Method. Englewood Cliffs, NJ: Prentice-Hall.

Borrie, W. D. 1959. The Cultural Integration of Immigrants: A Survey Based Upon the Papers and Proceedings of the UNESCO Conference Held in Havana, April 1956. Paris: UNESCO.

Boyd, Monica. 1997. "Migration Policy, Female Dependency and Family Membership: Canada and Germany." Pp. 142-169 in Women and the Canadian Welfare State: Challenge and Change, edited by P. M. Evans and G. R. Wekerle. Toronto; Buffalo; London: University of Toronto Press.

Brettell, Caroline and James Frank Hollifield, eds. 2015. Migration Theory: Talking across Disciplines. New York: Routledge.

Bussemaker, Jet and Kees van Kersbergen. 1994. "Gender and Welfare States: Some Theoretical Reflections." Pp. 8-25 in Gendering Welfare States, edited by D. Sainsbury. London; Thousand Oaks, Calif: SAGE Publications Ltd.

Cooley, Charles Horton. 1902. Human Nature and the Social Order. New York: C. Scribner's Sons.

Daly, Mary. 1994. "Comparing Welfare States: Towards a Gender Friendly Approach.” Pp. 101-117 in Gendering Welfare States, edited by D. Sainsbury. London; Thousand Oaks, Calif.: SAGE Publications Ltd.

Daly, Mary. 2000. The Gender Division of Welfare: The Impact of the British and German Welfare States. Cambridge, UK; New York: Cambridge University Press.

Denzin, Norman K. 1978. The Research Act: A Theoretical Introduction to Sociological Methods. New York: McGraw-Hill.

Denzin, Norman K. 1992. Symbolic Interactionism and Cultural Studies: The Politics of Interpretation. Oxford, UK; Cambridge, USA: Blackwell.

Dewey, John. 1896. "The Reflex Arc Concept in Psychology." Psychological review 3 (4):357-370.

Eisenstadt, S. N. 1952a. "The Process of Absorption of New Immigrants in Israel." Human Relations 5 (3):223-246. doi:10.1177/001872675200500301.

Eisenstadt, S. N. 1952b. "Institutionalization of Immigrant Behaviour." Human Relations 5 (4):373-395. doi:10.1177/001872675200500404.

Eisenstadt, S. N. 1953. "Analysis of Patterns of Immigration and Absorption of Immigrants." Population Studies 7 (2):167-180. doi:10.2307/2172030.

Eisenstadt, S. N. 1954. The Absorption of Immigrants. London: Routledge \& Paul.

Esping-Andersen, Gøsta. 1990. The Three Worlds of Welfare Capitalism. Cambridge, UK: Polity Press.

Esser, Hartmut. 1980. Aspekte der Wanderungssoziologie: Assimilation und Integration von Wanderern, ethnischen Gruppen und Minderheiten: eine handlungstheoretische Analyse. Darmstadt; Neuwied: Luchterhand.

FitzGerald, David. 2015. "The Sociology of International Migration." Pp. 115-147 in Migration Theory: Talking across Disciplines, edited by C. Brettell and J. F. Hollifield. New York: Routledge.

Gangl, Markus and Andrea Ziefle. 2015. "The Making of a Good Woman: Extended Parental Leave Entitlements and Mothers' Work Commitment in Germany.” American Journal of Sociology 121 (2):511-563. doi:10.1086/682419.

Gans, Herbert J. 1992. "Comment: Ethnic Invention and Acculturation, a Bumpy-Line Approach." Journal of American Ethnic History 12 (1):42-52.

Gordon, Milton Myron. 1964. Assimilation in American Life: The Role of Race, Religion, and National Origins. New York: Oxford University Press. 
Green, Simon. 2013. "Germany: A Changing Country of Immigration." German Politics 22 (3):333-351. doi:10.1080/09644008.2013.832757.

Gustafsson, Siv. 1992. "Separate Taxation and Married Women's Labor Supply: A Comparison of West Germany and Sweden." Journal of Population Economics 5 (1):61-85.

Heisler, Barbara Schmitter. 1992. "The Future of Immigrant Incorporation: Which Models? Which Concepts?" The International Migration Review 26 (2):623-645. doi: $10.2307 / 2547074$.

James, William and Rouben Mamoulian Collection (Library of Congress). 1890. The Principles of Psychology. New York: H. Holt and company.

Koopmans, Ruud. 2013. "Multiculturalism and Immigration: A Contested Field in Cross-National Comparison.” Annual Review of Sociology 39 (1):147-169. doi:10.1146/annurev-soc-071312-145630.

Leitner, Sigrid. 2013. Varianten von Familialismus: eine historisch vergleichende Analyse der Kinderbetreuungs- und Altenpflegepolitiken in kontinentaleuropäischen Wohlfahrtsstaaten. Berlin: Duncker \& Humblot.

Lewis, Jane. 1992. "Gender and the Development of Welfare Regimes." Journal of European Social Policy 2 (3):159-173. doi:10.1177/095892879200200301.

Lewis, Jane and Ilona Ostner. 1994. "Gender and the Evolution of European Social Policies." ZeS-Arbeitspapier, Nr. 4/94. Universität Bremen, Zentrum für Sozialpolitik, Bremen.

Linton, Ralph. 1936. The Study of Man: An Introduction. New York: D. AppletonCentury Co.

Lopata, Helena Znaniecka. 2003. "Symbolic Interactionism and I." Symbolic Interaction 26 (1):151-172.

Mandel, Hadas and Michael Shalev. 2009. "How Welfare States Shape the Gender Pay Gap: A Theoretical and Comparative Analysis.” Social Forces 87 (4):18731911. doi:10.1353/sof.0.0187.

Mead, George H. 1910. "What Social Objects Must Psychology Presuppose?” Journal of Philosophy, Psychology and Scientific Methods 7 (7):174-180.

Mead, George Herbert and Charles W. Morris. 1934. Mind, Self \& Society from the Standpoint of a Social Behaviorist. Chicago, Ill.: The University of Chicago Press.

Merton, Robert King. 1957. Social Theory and Social Structure. Glencoe, Ill.: Free Press.

Meyer, Traute. 1994. "The German and British Welfare States as Employers: Patriarchal or Emancipatory?" Pp. 62-81 in Gendering Welfare States, edited by D. Sainsbury. London; Thousand Oaks, Calif.: SAGE Publications Ltd.

O'Connor, Julia S. 1993. "Gender, Class and Citizenship in the Comparative Analysis of Welfare State Regimes: Theoretical and Methodological Issues." The British Journal of Sociology 44 (3):501-518. doi:10.2307/591814.

Orloff, Ann Shola. 1993. "Gender and the Social Rights of Citizenship: The Comparative Analysis of Gender Relations and Welfare States." American Sociological Review 58 (3):303-328. doi:10.2307/2095903.

Park, Robert Ezra. 1914. "Racial Assimilation in Secondary Groups with Particular Reference to the Negro." American Journal of Sociology 19 (5):606-623. doi:10.1086/212297.

Park, Robert Ezra and Ernest Watson Burgess. 1921. Introduction to the Science of Sociology. Chicago, Ill.: The University of Chicago Press.

Petrus, Han. 2005. Soziologie der Migration: Erklärungsmodelle, Fakten, politische Konsequenzen, Perspektiven. Stuttgart: Lucius \& Lucius. 
Rumbaut, Ruben G. 1997. "Assimilation and Its Discontents: Between Rhetoric and Reality.” The International Migration Review 31 (4):923-960. doi:10.2307/2547419.

Sainsbury, Diane. 1994. "Women's and Men's Social Rights: Gendering Dimensions of Welfare States." Pp. 150-169 in Gendering Welfare States, edited by D. Sainsbury. London: SAGE Publications Ltd.

Schachter, Ariela. 2016. "From 'Different' to 'Similar': An Experimental Approach to Understanding Assimilation." American Sociological Review 81 (5):981-1013. doi:10.1177/0003122416659248.

Schönwälder, Karen. 2010. "Germany: Integration Policy and Pluralism in a SelfConscious Country of Immigration.” Pp. 152-169 in The Multiculturalism Backlash. European Discourses, Policies and Practices, edited by S. Vertovec and S. Wessendorf. London; New York: Routledge.

Stryker, Sheldon. 1980. Symbolic Interactionism: A Social Structural Version. Menlo Park, Calif.: Benjamin/Cummings Pub. Co.

Stryker, Sheldon. 2001. "Traditional Symbolic Interactionism, Role Theory, and Structural Symbolic Interactionism: The Road to Identity Theory.” Pp. 211-231 in Handbook of Sociological Theory, Handbooks of Sociology and Social Research, edited by J. H. Turner. New York, NY: Springer US.

Turner, Ralph H. 1962. "Role Taking: Process Versus Conformity." Pp. 20-40 in Human Behavior and Social Processes, edited by A. M. Rose. Boston: Houghton Mifflin.

Turner, Ralph H. 2001. "Role Theory." Pp. 233-254 in Handbook of Sociological Theory, Handbooks of Sociology and Social Research, edited by J. H. Turner. New York, NY: Springer US.

Vertovec, Steven and Susanne Wessendorf. 2010. The Multiculturalism Backlash: European Discourses, Policies and Practices. London; New York: Routledge.

von Oertzen, C. and A. Rietzschel. 1997. "Comparing the Post-War Germanies: Breadwinner Ideology and Women's Employment in the Divided Nation, 1948-1970." International Review of Social History 42:175-196.

Waldinger, Roger. 2003. "Foreigners Transformed: International Migration and the Remaking of a Divided People." Diaspora 12 (2):247-272.

Waters, M. C. and T. R. Jimenez. 2005. "Assessing Immigrant Assimilation: New Empirical and Theoretical Challenge." Annual Review of Sociology 31:105-125.

West, Candace and Don H. Zimmerman. 1987. "Doing Gender." Gender and Society 1 (2):125-151.

Zhou, Min. 1997. "Segmented Assimilation: Issues, Controversies, and Recent Research on the New Second Generation." The International Migration Review 31 (4):975-1008. doi:10.2307/2547421.

Billig, Michael. 1988. Ideological Dilemmas: A Social Psychology of Everyday Thinking. London; Newbury Park: Sage Publications.

Blumer, Herbert. 1969. Symbolic Interactionism: Perspective and Method. Englewood Cliffs, NJ: Prentice-Hall.

Butler, Judith. 1990. Gender Trouble: Feminism and the Subversion of Identity. New York: Routledge.

Chamberlain-Salaun, Jennifer, Jane Mills and Kim Usher. 2013. "Linking Symbolic Interactionism and Grounded Theory Methods in a Research Design: From Corbin and Strauss' Assumptions to Action." SAGE Open 3 (3). doi:10.1177/ 2158244013505757. 
Charmaz, Kathy. 2000. "Grounded Theory: Objectivist and Constructivist Methods." Pp. 509-536 in The Handbook of Qualitative Research, edited by N. K. Denzin and Y. S. Lincoln. Thousand Oaks, Calif.: Sage Publications.

Charmaz, Kathy. 2006. Constructing Grounded Theory. London; Thousand Oaks, Calif.: Sage Publications.

Clarke, Adele E. 2003. "Situational Analyses: Grounded Theory Mapping after the Postmodern Turn." Symbolic Interaction 26 (4):553-576. doi:10.1525/ si.2003.26.4.553.

Corbin, J. and A. Strauss. 1990. "Grounded Theory Research - Procedures, Canons and Evaluative Criteria." Zeitschrift Fur Soziologie 19 (6):418-427.

Corbin, Juliet M. and Anselm L. Strauss. 2015. Basics of Qualitative Research: Techniques and Procedures for Developing Grounded Theory. Los Angeles: SAGE.

Denzin, Norman K. 1978. The Research Act: A Theoretical Introduction to Sociological Methods. New York: McGraw-Hill.

Edley, Nigel. 2001. "Analysing Masculinity: Interpretative Repertoires, Ideological Dilemmas and Subject Positions." Pp. 189-227 in Discourse as Data: A Guide for Analysis, edited by M. Wetherell, S. Taylor and S. J. Yates. London; Thousand Oaks, Calif.: Sage Publications.

Ellis, Carolyn and Arthur Bochner. 2000. "Autoethnography, Personal Narrative, Reflexivity: Researcher as Subject.” Pp. 733-768 in Handbook of Qualitative Research, edited by N. K. Denzin and Y. S. Lincoln. Thousand Oaks, Calif.: Sage Publications.

Ellis, Carolyn, Tony E. Adams and Arthur P. Bochner. 2011. "Autoethnography: An Overview." Forum: Qualitative Social Research 12 (1). doi:10.17169/fqs-12.1.1589.

Eyben, Rosalind. 2008. "Becoming a Feminist in Aidland." Pp. 149-169 in Gender and Family among Transnational Professionals, edited by A. Coles and A.-M. Fechter. New York: Routledge.

Foucault, Michel. 1972. The Archaeology of Knowledge. London: Tavistock Publications.

Gergen, Kenneth J. 1985. "Social Constructionist Inquiry: Context and Implications." Pp. 3-18 in The Social Construction of the Person, edited by K. J. Gergen and K. E. Davis. New York: Springer-Verlag.

Glaser, Barney G. 1978. Theoretical Sensitivity: Advances in the Methodology of Grounded Theory. Mill Valley, Calif:: Sociology Press.

Glaser, Barney G. 2001. The Grounded Theory Perspective: Conceptualization Contrasted with Description. Mill Valley, Calif.: Sociology Press.

Glaser, Barney G. 2002. "Constructivist Grounded Theory?" Forum: Qualitative Social Research 3 (3). doi:10.17169/fqs-3.3.825.

Glaser, Barney G. and Anselm L. Strauss. 1967. The Discovery of Grounded Theory; Strategies for Qualitative Research. Chicago: Aldine Pub. Co.

Holstein, James A. and Jaber F. Gubrium. 1995. The Active Interview. Thousand Oaks: SAGE Publications.

Mead, George Herbert and Charles W. Morris. 1934. Mind, Self \& Society from the Standpoint of a Social Behaviorist. Chicago, Ill.: The University of Chicago Press.

Morison, Tracy and Catriona Macleod. 2013. "A Performative-Performance Analytical Approach.” Qualitative Inquiry 19 (8):566-577. doi:10.1177/1077800413494344.

Nentwich, Julia C. and Tracy Morison. 2017. "Performing the Self: Performativity and Discursive Psychology.” Pp. 209-229 in American Psychological Association Handbook of the Psychology of Women, Vol. 1: History, Theory, and Battlegrounds, edited by C. B. Travis and J. W. White. Washington, DC: American Psychological Association. 
Potter, Jonathan and Margaret Wetherell. 1987. Discourse and Social Psychology: Beyond Attitudes and Behaviour. London: Sage.

Reed-Danahay, Deborah. 1997. Auto/Ethnography: Rewriting the Self and the Social. Oxford; New York: Berg.

Reynolds, Jill, Margaret Wetherell and Stephanie Taylor. 2007. "Choice and Chance: Negotiating Agency in Narratives of Singleness." The Sociological Review 55 (2):331-351. doi:10.1111/j.1467-954X.2007.00708.x.

Strauss, Anselm L. 1987. Qualitative Analysis for Social Scientists. Cambridge, UK; New York: Cambridge University Press.

Strauss, Anselm L. and Juliet M. Corbin. 1990. Basics of Qualitative Research: Grounded Theory Procedures and Techniques. Newbury Park, Calif.: Sage Publications.

Taylor, Stephanie. 2006. "Narrative as Construction and Discursive Resource." Narrative Inquiry 16 (1):94-102.

Taylor, Stephanie and Karen Littleton. 2006. "Biographies in Talk: A Narrative-Discursive Research Approach.” Qualitative Sociology Review 2 (1):22-38.

Thornberg, Robert and Kathy Charmaz. 2014. "Grounded Theory and Theoretical Coding." Pp. 153-169 in The Sage Handbook of Qualitative Data Analysis. Los Angeles, Calif. [u.a.]: Sage.

Wetherell, Margaret. 1998. "Positioning and Interpretative Repertoires: Conversation Analysis and Post-Structuralism in Dialogue." Discourse \& Society 9 (3):387-412.

Wetherell, Margaret, Stephanie Taylor and Simeon Yates. 2001. Discourse as Data: A Guide for Analysis. London; Thousand Oaks, Calif.: Sage Publications.

Wetherell, Margaret, Simeon Yates, Stephanie Taylor and Open University. 2001. Discourse Theory and Practice: A Reader. London; Thousand Oaks, Calif.: SAGE.

Boyd, Monica. 1997. "Migration Policy, Female Dependency and Family Membership: Canada and Germany." Pp. 142-169 in Women and the Canadian Welfare State: Challenge and Change, edited by P. M. Evans and G. R. Wekerle. Toronto; Buffalo; London: University of Toronto Press.

de Beauvoir, Simone. 1953. The Second Sex. New York: Knopf.

England, Paula. 2010. "The Gender Revolution." Gender \& Society 24 (2):149-166. doi:10.1177/0891243210361475.

Kandiyoti, Deniz. 1988. "Bargaining with Patriarchy.” Gender and Society 2 (3):274-290.

Kofman, Eleonore. 1999. "Female 'Birds of Passage' a Decade Later: Gender and Immigration in the European Union.” International Migration Review 33 (2):269-299. doi: $10.2307 / 2547698$.

Lorber, Judith. 1994. Paradoxes of Gender. New Haven: Yale University Press.

Rosenfeld, Rachel A., Heike Trappe and Janet C. Gornick. 2004. "Gender and Work in Germany: Before and after Reunification." Annual Review of Sociology 30 (1):103-124. doi:10.1146/annurev.soc.30.012703.110531.

Sechiyama, Kaku. 2013. Patriarchy in East Asia: A Comparative Sociology of Gender. Leiden: Brill.

Charles, M. and K. Bradley. 2009. "Indulging Our Gendered Selves? Sex Segregation by Field of Study in 44 Countries.” American Journal of Sociology 114 (4):924-976. doi:10.1086/595942.

Fineman, Martha Albertson. 2000. "Cracking the Foundational Myths: Independence, Autonomy, and Self-Sufficiency." The American University Journal of Gender, Social Policy \& the Law 1:13-29. 
Johnson-Hanks, Jennifer. 2002. "On the Limits of Life Stages in Ethnography: Toward a Theory of Vital Conjunctures." American Anthropologist 104 (3):865-880. doi:10.1525/aa.2002.104.3.865.

Liversage, Anika. 2009. "Vital Conjunctures, Shifting Horizons: High-Skilled Female Immigrants Looking for Work.” Work Employment and Society 23 (1):120-141. doi:10.1177/0950017008099781.

Bielby, Denise Del Vento and William T. Bielby. 1984. "Work Commitment, Sex-Role Attitudes, and Women's Employment." American Sociological Review 49 (2):234247. doi: $10.2307 / 2095573$.

DiPrete, T. A., C. C. Eller, T. Bol and H. G. van de Werfhorst. 2017. "School-to-Work Linkages in the United States, Germany, and France." American Journal of Sociology 122 (6):1869-1938. doi:10.1086/691327.

Liversage, Anika. 2009a. "Finding a Path: Investigating the Labour Market Trajectories of High-Skilled Immigrants in Denmark." Journal of Ethnic and Migration Studies 35 (2):203-226. doi:10.1080/13691830802586195.

Liversage, Anika. 2009b. "Vital Conjunctures, Shifting Horizons: High-Skilled Female Immigrants Looking for Work." Work Employment and Society 23 (1):120-141. doi:10.1177/0950017008099781.

Brinton, Mary C. 2001. "Married Women's Labor in East Asian Economies." Pp. 1-37 in Women's Working Lives in East Asia, edited by M. C. Brinton. Stanford, CA: Stanford University Press.

Hsieh, Kuang-Hua and Robert L. Burgess. 1994. "Marital Role Attitudes and Expected Role Behaviors of College Youth in Mainland China and Taiwan." Journal of Family Issues 15 (3):403-423. doi:10.1177/019251394015003004. 